\title{
Evaluating multi-year, multi-site data on the energy balance closure of eddy-covariance flux measurements at cropland sites in southwestern Germany
}

\author{
Ravshan Eshonkulov $^{1,3}$, Arne Poyda ${ }^{1}$, Joachim Ingwersen ${ }^{1}$, Hans-Dieter Wizemann ${ }^{2}$, Tobias K. D. Weber ${ }^{1}$, \\ Pascal Kremer $^{1}$, Petra Högy ${ }^{4}$, Alim Pulatov ${ }^{5}$, and Thilo Streck ${ }^{1}$ \\ ${ }^{1}$ Institute of Soil Science and Land Evaluation, Biogeophysics, University of Hohenheim, \\ Emil-Wolff Str. 27, 70593 Stuttgart, Germany \\ ${ }^{2}$ Institute of Physics and Meteorology, Physics and Meteorology, University of Hohenheim, \\ Garben Str. 30, 70593 Stuttgart, Germany \\ ${ }^{3}$ Environmental Protection and Ecology, Karshi Engineering Economic Institute, \\ Mustakillik Avenue 225, 180100 Karshi, Uzbekistan \\ ${ }^{4}$ Institute of Landscape and Plant Ecology, Plant Ecology and Ecotoxicology, University of Hohenheim, \\ August-von-Hartmann-Str. 3, 70593 Stuttgart, Germany \\ ${ }^{5}$ EcoGIS center, Tashkent Institute of Irrigation and Agricultural Mechanization Engineers, \\ Kary Niyoziy Str.39, 100000 Tashkent, Uzbekistan
}

Correspondence: Ravshan Eshonkulov (ravshan.eshonkulov@qmii.uz)

Received: 20 September 2018 - Discussion started: 24 September 2018

Revised: 22 December 2018 - Accepted: 3 January 2019 - Published: 30 January 2019

\begin{abstract}
The energy balance of eddy-covariance (EC) measurements is typically not closed, resulting in one of the main challenges in evaluating and interpreting EC flux data. Energy balance closure (EBC) is crucial for validating and improving regional and global climate models. To investigate the nature of the gap in EBC for agroecosystems, we analyzed EC measurements from two climatically contrasting regions (Kraichgau - KR - and Swabian Jura - SJ) in southwestern Germany. Data were taken at six fully equipped EC sites from 2010 to 2017. The gap in EBC was quantified by ordinary linear regression, relating the energy balance ratio (EBR), calculated as the quotient of turbulent fluxes and available energy, to the residual energy term. In order to examine potential reasons for differences in EBC, we compared the EBC under varying environmental conditions and investigated a wide range of possible controls. Overall, the variation in EBC was found to be higher during winter than summer. Moreover, we determined that the site had a statistically significant effect on EBC but no significant effect on either crop or region (KR vs SJ). The time-variable footprints of all EC stations were estimated based on data measured in 2015 , complimented by micro-topographic analyses along the pre-
\end{abstract}

vailing wind direction. The smallest mean annual energy balance gap was $17 \%$ in KR and $13 \%$ in SJ. Highest EBRs were mostly found for winds from the prevailing wind direction. The spread of EBRs distinctly narrowed under unstable atmospheric conditions, strong buoyancy, and high friction velocities. Smaller footprint areas led to better EBC due to increasing homogeneity. Flow distortions caused by the back head of the anemometer negatively affected EBC during corresponding wind conditions.

\section{Introduction}

Studying turbulent exchange at the land surface is important for assessing water cycling, plant growth, and carbon fluxes of ecosystems and for enhancing soil-crop, climate, and weather models. Currently, the best technique for determining these fluxes is the eddy-covariance (EC) method. It is considered the most direct and accurate measurement of turbulent fluxes in the soil-plant-atmosphere system (Baldocchi et al., 2001; Burba, 2013). In EC flux data, the mea- 
sured available energy (incoming net radiation minus ground heat flux) is generally higher than the sum of turbulent exchange fluxes (latent and sensible heat). Accordingly, either the turbulent fluxes are incompletely captured or the measured available energy is positively biased. This gap in energy balance closure (EBC) is a long-standing problem in EC measurements and is one of the most frequently discussed concerns in micrometeorological research (Foken, 2008a).

Globally, a large number of research sites have been established to, inter alia, study reasons for the energy imbalance. This includes the FLUXNET network, with more than 500 EC towers around the world (Wilson et al., 2002), and the AmeriFlux network operating in North, Central, and South America (Peng et al., 2017). An example is an energy balance experiment, which was conducted to determine the reasons for the energy imbalance of EC measurements over irrigated cotton fields. The results showed that the net radiation differed by up to $10 \mathrm{~W} \mathrm{~m}^{-2}$ across a single field (Kohsiek et al., 2007). In a review of EBC, Foken (2008b) summarized the most important factors for the energy imbalance as related to measurement errors of the energy balance components, incorrect sensor configurations, influences of heterogeneous canopy height, unconsidered energy storage terms in the soil-plant-atmosphere system, inadequate time averaging intervals, and long-wave eddies (mesoscale circulations; Foken, 2008b; Jacobs et al., 2008; Wilson et al., 2002). Additionally, the energy transport with near-surface secondary circulations (large eddies) cannot be measured with a single EC station (Cava et al., 2008; Foken, 2008b; Xu et al., 2017).

In parts, this may be rectified by altering the time averaging intervals. For example, Kidston et al. (2010) found that at a forest site, EBC peaked at $90 \%$ when applying a 240 min averaging interval. At a boreal forest site, Sánchez et al. (2010) applied a range of different time averaging intervals and found that increasing the interval from the traditional 30 min to 1 day improved the EBC from $75 \%$ to $100 \%$. However, this picture is inconclusive, since Oncley et al. (2007) found that increasing the time averaging interval up to $4 \mathrm{~h}$ at an irrigated cotton field did not result in a higher contribution of turbulent fluxes and that the contribution of low turbulent fluxes was less than $10 \mathrm{~W} \mathrm{~m}^{-2}$. In most cases, the standard $30 \mathrm{~min}$ averaging period is proven to be the best compromise for simultaneously capturing most of the turbulent fluxes while fulfilling the precondition of stationarity (Charuchittipan et al., 2014; Masseroni et al., 2014; Sun et al., 2006).

The influence of site characteristics (e.g., vegetation type, canopy height, and terrain) on the EBC has been studied extensively. Wilson et al. (2002) reported no clear differences in EBC between flat and sloped terrain sites across 22 research sites. A comparison of two different agroecosystems in China, a degraded grassland and a maize cropland, showed similar EBC of about $80 \%$ (Du et al., 2014). The comparison of a mature boreal jack pine forest and a jack pine clear-cut site by Kidston et al. (2010) revealed that depending on the surface characteristics, the loss of low frequencies can contribute significantly to the energy imbalance. Canopy height may impact EBC, although Wilson et al. (2002) found, in their study, that vegetation height did not control EBC. However, consideration of the stored energy in the soil-plantatmosphere zone can noticeably improve EBC (Jacobs et al., 2008; Meyers and Hollinger, 2004; Zeri and Sá, 2010). Meyers and Hollinger (2004) compared the energy stored or released by $\mathrm{CO}_{2}$ exchange and crop enthalpy change and showed that in their study maize stored more energy than soybean crops. Additionally, Eshonkulov et al. (2019) reported that mean EBC improved from $78 \%$ to $87 \%$ when minor energy storage and flux terms were taken into account during the main vegetation period. Lastly, the mismatch of measurement scales is also considered to be a reason for the energy imbalance (Sánchez et al., 2010; Xu et al., 2017).

During the last decade, the identification of the contributing source area (footprint) and evaluation of the representativeness of the EC flux data for the field of interest has received increased interest (Göckede et al., 2006; Kljun et al., 2004; Schmid, 2002). Knowledge about the footprint is important for clarifying whether the EC station measures local or nonlocal energy fluxes (Eugster and Merbold, 2015; Pirk et al., 2017). Currently, there are a variety of models in use for estimating footprint areas. While most analytical footprint models assume a homogeneous flux source area, footprint calculations for heterogeneous sites require greater computational effort and detailed information on surface characteristics (Mauder et al., 2013). Despite the existing methods and studies, Stoy et al. (2013) concluded that the relationship between the footprint and EBC in agricultural cropland has not been sufficiently studied.

Therefore, the presented study evaluates the energy balance at agricultural croplands. The analyses are based on EC measurements conducted from 2010 to 2017 at six fully equipped sites in two climatically different regions of southwestern Germany. We hypothesized that multi-year, multisite observations will provide new insights into the nature of the energy imbalance of EC flux measurements. The objectives of this study are to evaluate if the crop type, site characteristics, wind direction, atmospheric conditions, and footprint area act as controls on the EBC.

\section{Materials and methods}

\subsection{Site description}

The study sites in the Kraichgau region (KR) were located at "Katharinentalerhof", characterized by mostly flat terrain, and are located approximately $4 \mathrm{~km}$ north of the city Pforzheim $\left(48.92^{\circ} \mathrm{N}, 8.70^{\circ} \mathrm{E}\right)$. Three EC stations (EC1, $\mathrm{EC} 2$, and EC3) were installed at adjacent fields with the respective areas of 14.9, 23.6, and 15.8 ha (Fig. 1). The prevailing wind direction is west. A former landfill site is located 


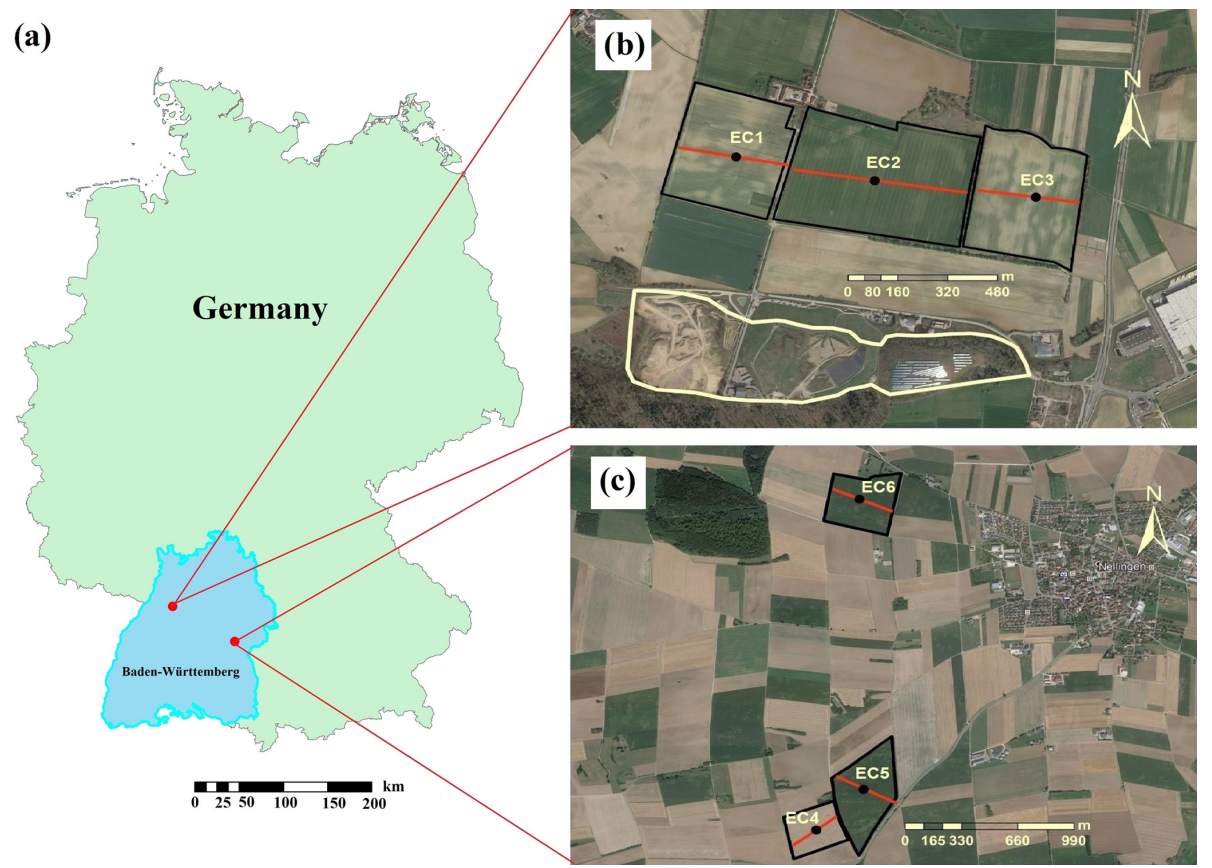

Figure 1. (a) Geographical overview (a) and locations of the study sites and EC stations in Kraichgau (b) and Swabian Jura (c) (Google Earth; KR on 31 March 2017 and SJ on 26 August 2016). Red transect lines indicate positions of conducted micro-topographic measurements along the prevailing wind directions. The yellow line demarks the boundaries of a former landfill site (b).

approximately $500 \mathrm{~m}$ to the south of the experimental fields whose maximum elevation is about $41 \mathrm{~m}$ above its surroundings. KR is one of the warmest regions in Germany, with a mean temperature and annual precipitation of $9.4^{\circ} \mathrm{C}$ and $890 \mathrm{~mm}$ in 1981-2010 (meteorological station PforzheimIspringen, German Weather Service, located about $3 \mathrm{~km}$ from the research sites). The soils of this region developed from deep loess layers overlying a shell limestone. Detailed information about meteorological and soil conditions can be found in Table 1 and in Imukova et al. (2016), Ingwersen et al. (2015), and Wizemann et al. (2014).

Due to its higher elevation, the Swabian Jura region (SJ) is characterized by a colder and harsher climate compared to KR. The prevailing wind direction is southwest to west. Mean temperature and annual precipitation were $7.5^{\circ} \mathrm{C}$ and $1042 \mathrm{~mm}$ in 1981-2010 (Meteorological station Merklingen, German Weather Service, about $2 \mathrm{~km}$ from the research sites). Information about meteorological and soil variables is given in Table 1. Accordingly, crops are generally sowed and harvested later than in KR. SJ is the largest contiguous karst landscape in Germany, with generally rather shallow soils. The study sites are located close to the town of Merklingen (Fig. 1). The areas of the three research fields at EC4, EC5, and EC6 were 8.7, 16.7, and 13.4 ha, respectively. While EC4 and EC5 were adjacent fields, EC6 was situated $1.5 \mathrm{~km}$ to the north (Fig. 1).

The crop rotation in SJ was more diverse than in KR, and the most frequently grown crops were winter wheat and silage maize (Table 2). In $50 \%$ of the years on-site in KR, winter wheat was cultivated; this value was only $25 \%$ in SJ. KR showed a lower variety in cultivated crops to SJ, with three in KR and six in SJ. At all sites, farmers frequently grew cover crops between winter and summer crops. These were mainly mustard, phacelia, or multi-species mixtures.

\subsection{Eddy-covariance measurements}

One EC station was installed at the center of each field site in spring 2009 (Ingwersen et al., 2011; Wizemann et al., 2014). All stations were equipped with a fast-response $\mathrm{CO}_{2} / \mathrm{H}_{2} \mathrm{O}$ open-path infrared gas analyzer (LI-7500; LICOR Biosciences, Lincoln, NE, USA) and a three-axis ultrasonic anemometer (CSAT3; Campbell Scientific Inc., Logan, UT, USA). The raw data of the gas analyzer and sonic anemometer were recorded at $10 \mathrm{~Hz}$ and stored on a CR3000 data logger (Campbell Scientific Inc., Logan, UT, USA). In early 2009, the CSAT3 orientation at EC1 and EC 3 was $230^{\circ}$, and at $\mathrm{EC} 2$, it was $255^{\circ}$. In late April 2010, the orientation was changed to $170^{\circ}$ and varied over the subsequent years between 160 and $190^{\circ}$, ensuring that winds from the prevailing wind direction (west and east) enter the anemometer from the side. In SJ, the mean CSAT3 orientation was $220^{\circ} \pm 15$ from late March 2010 until the end of 2017. The gas analyzers were factory-calibrated biannually. Sensor heights were adjusted to account for increasing canopy heights, particularly during the vegetation periods of maize. This ensured that the distance between sensors and canopy was roughly 
Table 1. Main characteristics of the investigated sites.

\begin{tabular}{l|lll|lll}
\hline Region & \multicolumn{3}{c|}{ Kraichgau } & \multicolumn{3}{c}{ Swabian Jura } \\
\hline Station name & EC1 & EC2 & EC3 & EC4 & EC5 & EC6 \\
\hline Latitude $\left(^{\circ}\right)$ & $48.928496 \mathrm{~N}$ & $48.927743 \mathrm{~N}$ & $48.927199 \mathrm{~N}$ & $48.527214 \mathrm{~N}$ & $48.529780 \mathrm{~N}$ & $48.546632 \mathrm{~N}$ \\
Longitude $\left(^{\circ}\right)$ & $8.702782 \mathrm{E}$ & $8.708901 \mathrm{E}$ & $8.715950 \mathrm{E}$ & $9.769950 \mathrm{E}$ & $9.773474 \mathrm{E}$ & $9.774280 \mathrm{E}$ \\
\hline Elevation $(\mathrm{m})$ & 319 & 320 & 319 & 682 & 681 & 690 \\
\hline Soil type & & Stagnic Luvisol & & Calcic Luvisol & Anthrosol & Rendzic \\
(WRB, 2014) & & & & & & Leptosol \\
\hline
\end{tabular}

Table 2. Crop grown at the six study sites from 2010 to 2017 (harvest year).

\begin{tabular}{l|lll|lll}
\hline Region & \multicolumn{3}{|c|}{ Kraichgau } & \multicolumn{3}{c}{ Swabian Jura } \\
\hline & \multicolumn{3}{|c|}{ Sites } & \multicolumn{3}{c}{ Sites } \\
\hline Harvest year & EC1 & EC2 & EC3 & EC4 & EC5 & EC6 \\
\hline 2010 & SM & WR & WW & WR & WW & SM \\
2011 & WW & WW & SM & WW & SM & WW \\
2012 & WR & SM & WW & SB & SM & WB \\
2013 & WW & WW & WR & WR & WB & SM \\
2014 & SM & SM & WW & WW & SP & WW \\
2015 & WW & WW & SM & WW & SM & WB \\
2016 & GM & WR & WW & SB & SM & SM \\
2017 & WW & WW & WW & SM & WB & WB \\
\hline
\end{tabular}

WW is winter wheat, WR is winter rapeseed, $\mathrm{SM}$ is silage maize, GM is grain maize, SB is summer barley, WB is winter barley, and SP is spelt.

2-3 m. Maximal sensor heights in KR and SJ were $6.00 \mathrm{~m}$ at EC2 (2014) and $4.80 \mathrm{~m}$ at EC6 (2010), and the minimal sensor height was approximately $2 \mathrm{~m}$ in both regions. Each EC system was powered by two $12 \mathrm{~V}$ batteries (each $240 \mathrm{Ah}$ ) charged by four $20 \mathrm{~W}$ solar panels. To enable continuous EC measurements during winter, portable fuel cell systems (Efoy Pro 800 Duo, FSC Energy AG, Brunnthal-Nord, Germany) were installed in autumn 2015: one at EC2 and one at EC6. At the others stations the LI-7500 was shut down during the winter, mostly from late November to mid-March.

Net radiation was measured using a four-component radiometer (NR01, Hukseflux Thermal Sensors, Delft, The Netherlands). The radiometers were placed above the cropped field area in close proximity to the EC stations. Air temperature and relative humidity were measured at a height of $2 \mathrm{~m}$ at each EC station using a temperature and relative humidity probe (HMP45C, Vaisala Inc, Helsinki, Finland). Soil temperature was measured at the depths of $0.02,0.06,0.15$, 0.30 , and $0.45 \mathrm{~m}$ (107 Thermistor probe, Campbell Scientific Inc., Logan, UT, UK). To measure the soil heat flux near the EC stations, three heat flux plates (HFP01, Hukseflux Thermal sensors, Delft, The Netherlands) were installed at a depth of $0.08 \mathrm{~m}$. The soil volumetric water content at $0.05,0.15$,
$0.30,0.45$, and $0.75 \mathrm{~m}$ depth was monitored with frequencydomain reflectometry sensors (CS616, Campbell Scientific Inc., Logan, UT, USA). In the shallow soil at EC6, however, soil variables could be measured only down to $0.3 \mathrm{~m}$. Data from thermistor $(0.02$ and $0.06 \mathrm{~m})$ and water content sensors $(0.05 \mathrm{~m})$ were used to calculate the soil heat storage between the soil heat flux plates and the ground surface (Eshonkulov et al., 2019; Wizemann et al., 2014). Precipitation was measured with a $0.2 \mathrm{~mm}$ tipping bucket rain gauge (ARG 100, Environmental Measurements Ltd., North Shields, UK), which was installed $1 \mathrm{~m}$ above ground. The rain gauges were recalibrated once per year.

\section{Data processing and quality control}

High-frequency raw data from 2010 to 2017 were processed with a $30 \mathrm{~min}$ averaging interval using the software package TK3.1 (Mauder et al., 2013). The following settings were used to compute latent and sensible heat flux: spike detection (Vickers and Mahrt, 1997), planar fit coordinate rotation (Wilczak et al., 2001), correction of spectral loss (Moore, 1986), sonic virtual temperature conversion into actual temperature (Schotanus et al., 1983), and correction for density fluctuations (Webb et al., 1980). Additionally, the raw data of 2015 were processed with the software Eddypro ${ }^{\circledR}$ (Version 6.2.1, LI-COR Inc., 2012) to obtain input parameters (Obukhov length, standard deviation of lateral velocity fluctuations after rotation, friction velocity, mean wind speed, and direction) for deriving flux source area (footprint). Data processing and correction in EddyPro ${ }^{\circledR}$ were conducted with the same settings as in TK 3.1. Both programs yield comparable results (Fratini and Mauder, 2014).

The nine flag system after Foken et al. (2004) was used as the quality criterion. For the evaluation, we used only data with quality flags $1-3$, as suggested by Mauder and Foken (2011). Moderate (flags 4-6) and poor-quality (flags 7-9) data were discarded. In a second step, a median filter was applied for additional de-spiking of half-hourly fluxes. The filter removes all fluxes exceeding 5 times the median of the previous 3 days (Demyan et al., 2016). No gap-filling was performed in this study. 


\subsection{Energy balance closure of eddy-covariance measurements}

In the ideal case, the surface energy balance obeys the following equation:

$R_{\mathrm{n}}-G=\mathrm{LE}+H$,

where $R_{\mathrm{n}}$ is the incoming net radiation, LE is the latent heat flux, $H$ is the sensible heat flux (both positive upwards), and $G$ is the ground heat flux (positive downwards). All components are expressed in $\mathrm{W} \mathrm{m}^{-2}$. Note that in Eq. (1) minor flux terms such as energy storage in the canopy or energy conversion by photosynthesis are neglected. All available filtered half-hourly flux data of the four terms in Eq. (1) were used to calculate the EBC. Three measures were used to evaluate the EBC. Firstly, we determined the slope and intercept from ordinary linear regression $(\mathrm{OLR})$ of turbulent fluxes $(H+\mathrm{LE})$ against available energy $\left(R_{\mathrm{n}}-G\right)$. In the ideal case of a fully closed energy balance, the slope and intercept of the linear regression are equal to 1 and zero, respectively (Ping et al., 2011; Wilson et al., 2002). In this study, we also considered the intercept $\left(\mathrm{W} \mathrm{m}^{-2}\right)$ of the OLR in evaluating EBC, as suggested by Franssen et al. (2010).

Secondly, we calculated the energy balance ratio (EBR) as

$\mathrm{EBR}=\frac{H+\mathrm{LE}}{R_{\mathrm{n}}-G}$.

Thirdly, we compared the energy balance residual (Res; $\mathrm{W} \mathrm{m}^{-2}$ ) given by

Res $=R_{\mathrm{n}}-G-H-$ LE.

\subsection{Atmospheric conditions}

As a proxy for the role of shear and buoyancy in the production or consumption of turbulent kinetic energy, we used the friction velocity, $u^{*}\left(\mathrm{~m} \mathrm{~s}^{-1}\right)$, and the kinematic virtual temperature flux, respectively. The latter is the covariance $\left(w^{\prime} T_{\mathrm{v}}^{\prime}\right)$ between vertical wind speed $(w)$ and virtual temperature $\left(T_{\mathrm{v}}\right)$. As the virtual temperature can be replaced by the sonic temperature $\left(T_{\mathrm{s}}\right)$ with negligible loss of accuracy (Kaimal and Gaynor, 1991), we computed the virtual temperature flux from the covariance $\left(w^{\prime} T_{\mathrm{s}}^{\prime}\right)$ between $w$ and $T_{\mathrm{s}}$.

The relationship between atmospheric stability and the EBC was examined using the dimensionless atmospheric stability parameter $\zeta$ defined by Stull (1988):

$\zeta=z_{\mathrm{m}} / L$

where $z_{\mathrm{m}}(\mathrm{m})$ is the measurement height of the sonic anemometer and $L(\mathrm{~m})$ is the Obukhov length. The stability parameter expresses the relative roles of shear and buoyancy. Using $\zeta$, the stability of the atmosphere can be divided into three classes (Franssen et al., 2010): stable $(\zeta \geq 0.1)$, neutral $(-0.1<\zeta<0.1)$, and unstable $(\zeta \leq-0.1)$.

\subsection{Footprint analyses and micro-topography}

To determine the relationship between the contributing source area of turbulent fluxes and the EBC, we performed footprint analyses. We used the flux footprint prediction online tool of a simple two-dimensional parameterization (Kljun et al., 2015, http://geography.swansea.ac.uk/nkljun/ ffp/www/, last access: 17 July 2018). The footprint parameterization uses the Lagrangian stochastic particle dispersion model (Kljun et al., 2002). As input parameters to the model, we used displacement height, $z_{\mathrm{d}}(\mathrm{m})$, mean wind speed $\left(\mathrm{m} \mathrm{s}^{-1}\right)$, Obukhov length $(\mathrm{m})$, standard deviation of horizontal wind speed $\left(\mathrm{m} \mathrm{s}^{-1}\right)$, friction velocity, $u^{*}\left(\mathrm{~m} \mathrm{~s}^{-1}\right)$, wind direction $\left({ }^{\circ}\right)$, and measurement height above the ground surface, $z_{\mathrm{m}}(\mathrm{m})$, which was calculated by

$z_{\mathrm{m}}=z_{\text {receptor }}-z_{\mathrm{d}}$

where $z_{\text {receptor }}$ is the height of the sonic anemometer and the gas analyzer, and $z_{\mathrm{d}}$ is calculated by

$z_{\mathrm{d}}=0.67 \cdot z_{\mathrm{can}}$

where $z_{\mathrm{can}}(\mathrm{m})$ is the time-variable canopy height because of crop growth. This was accounted for by biweekly measurements and was considered in TK3.1 for the respective 2-week periods. Data for footprint analyses were constrained to $u^{*}>0.1 \mathrm{~m} \mathrm{~s}^{-1}$ and $\zeta \geq-15.5$.

Additionally, the micro-topography of the EC sites was determined along a transect in the prevailing wind direction (Fig. 1). About every two meters, the elevation of the fields above mean sea level was measured with a differential global positioning system (Altus APS 3M, Septentrio, Belgium).

\subsection{Statistical analyses}

For the statistical analyses, we used all available data on energy fluxes from the onset of measurements (late March or early April) until harvest. In the case of maize, however, full data for the calculation of energy balances were generally available from May. Autocorrelation of the data was tested using the Durbin-Watson test (Faraway, 2014). Analysis of variance (ANOVA) was used to test for significant effects of region, site, year, and crops on EBC, for which linear mixed models were defined (Piepho et al., 2004). The data were assumed to be normally distributed but heteroscedastic due to the different years. We based these assumptions on graphical residual analyses. Generally, the factors of interest were defined as fixed, and interaction terms were considered. Remaining factors not included in the ANOVA were defined as random. Multiple contrast tests (Bretz et al., 2011) were performed to identify significant differences between the different factor levels. Unless indicated otherwise, the significance level was set to $\alpha=0.05$. Calculations were done using the statistical software R (R Core Team, 2014) and packages multcomp for simultaneous tests of linear mixed models (Hothorn et al., 2017), nlme for fitting and comparing 


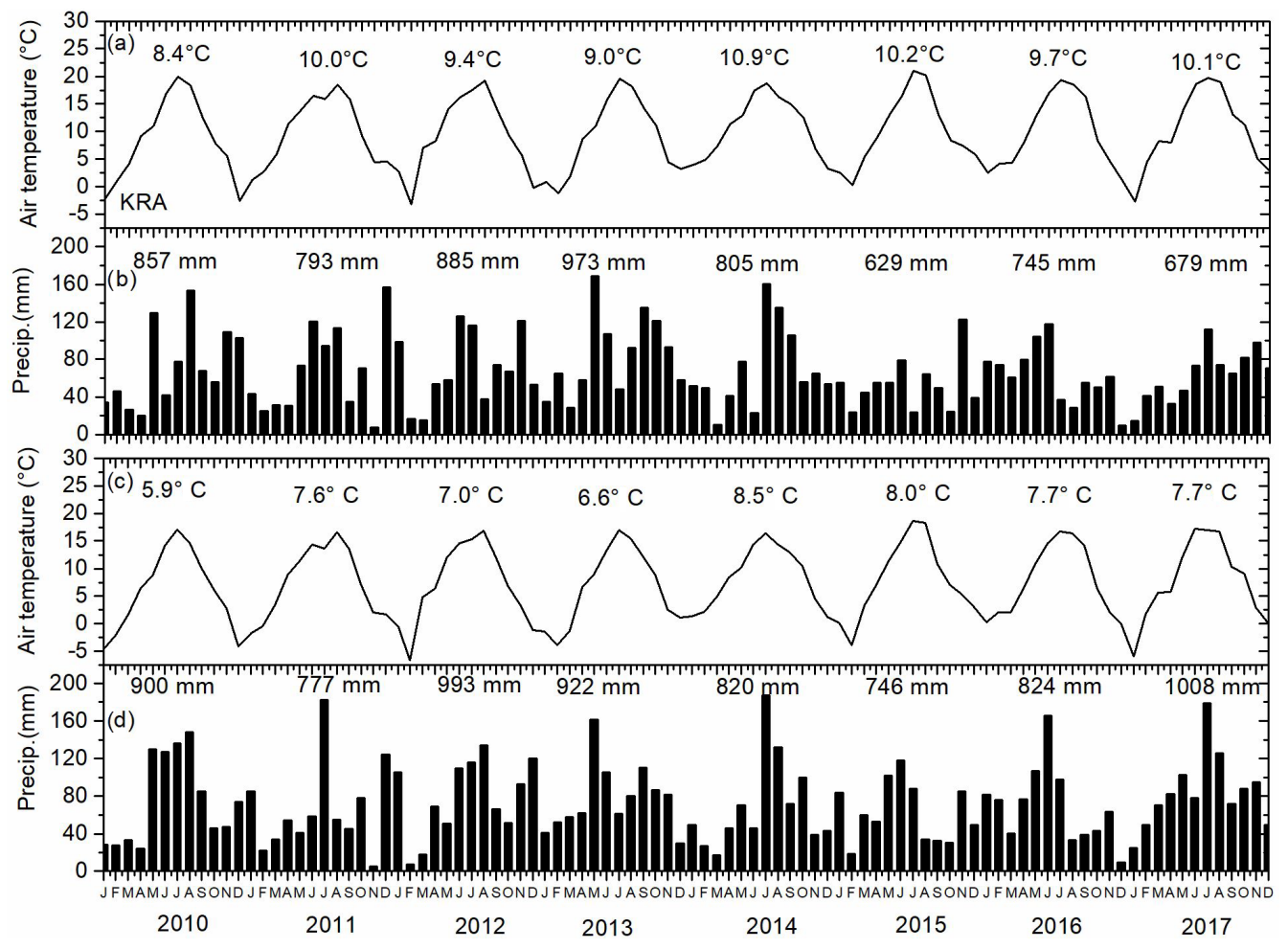

Figure 2. Mean monthly air temperatures and precipitation sums at the Kraichgau site EC1 and Swabian Jura site EC4 from 2010 to 2017. Annual mean temperatures and precipitation sums are given on top of the lines or bars.

the models (Pinheiro et al., 2016), gplots for creating plots (Gregory et al., 2009), and gdata for importing input data from files formatted by Microsoft Excel files (Gregory et al., 2017).

\section{Results}

\subsection{Meteorological and terrain conditions}

\subsubsection{Kraichgau}

At the KR sites, the annual mean air temperature ranged between $8.4^{\circ} \mathrm{C}$ in 2010 and $10.9^{\circ} \mathrm{C}$ in 2014 . The overall average was $9.8^{\circ} \mathrm{C}$ (Fig. 2a), which is $0.4^{\circ} \mathrm{C}$ higher than the 30-year climatological mean (1981-2010) measured at the meteorological station Pforzheim-Ispringen. The lowest and highest monthly mean temperature was $-3.2{ }^{\circ} \mathrm{C}$ in February 2012 and $21.1^{\circ} \mathrm{C}$ in July 2015 . The mean annual precipitation was $796 \mathrm{~mm}$, which is $93 \mathrm{~mm}$ lower than measured in Pforzheim-Ispringen. In 2013, the wettest year within the 8 -year period, total precipitation amounted to $973 \mathrm{~mm}$. The lowest annual precipitation $(629 \mathrm{~mm})$ was measured in 2015 (Fig. 2b).

Figure 3 shows the height transects along the prevailing wind direction. At the $\mathrm{KR}$ sites, the mean slopes along the transects were $0.4 \%,<0.01 \%$, and $0.3 \%$ at EC1, EC2, and EC3, respectively. The micro-relief of station EC1, located on a micro-bank, fluctuates more strongly than that of $\mathrm{EC} 2$. The immediate surroundings of EC2 are very homogeneous in elevation. Station EC3 was positioned in a microdepression. Overall, the three transects show that the KR fields can be regarded as flat, with EC2 being the flattest.

\subsubsection{Swabian Jura}

The mean temperature in $\mathrm{SJ}\left(7.4^{\circ} \mathrm{C}\right)$ was $2.4^{\circ} \mathrm{C}$ lower than in $\mathrm{KR}$, varying from $5.9^{\circ} \mathrm{C}$ in 2010 to $8.5^{\circ} \mathrm{C}$ in 2015 (Fig. 2c). As in KR, the lowest and highest mean monthly temperatures were recorded in February $2012\left(-6.6^{\circ} \mathrm{C}\right)$ and July 2015 $\left(18.6^{\circ} \mathrm{C}\right)$. The mean annual precipitation was $874 \mathrm{~mm}$. As in KR, 2015 was the year with the lowest precipitation. Highest total rainfall was measured in 2017, not in 2013 as in KR. November 2011 was the month with the lowest monthly cumulative precipitation $(5 \mathrm{~mm})$, and July 2014 was that with the highest (187 mm; Fig. 2d).

In SJ, only EC4 is relatively flat (Fig. 3). Its topography is comparable with that of EC1 in KR. The elevation along the transect at EC5 gently increases, with a mean slope of $0.6 \%$ from SE to NW. Station EC5 itself is situated in a local micro-depression. The topography of station EC6 differs considerably from that of the other fields. The station is positioned on the top of a ridge. Whereas in NW direction the 


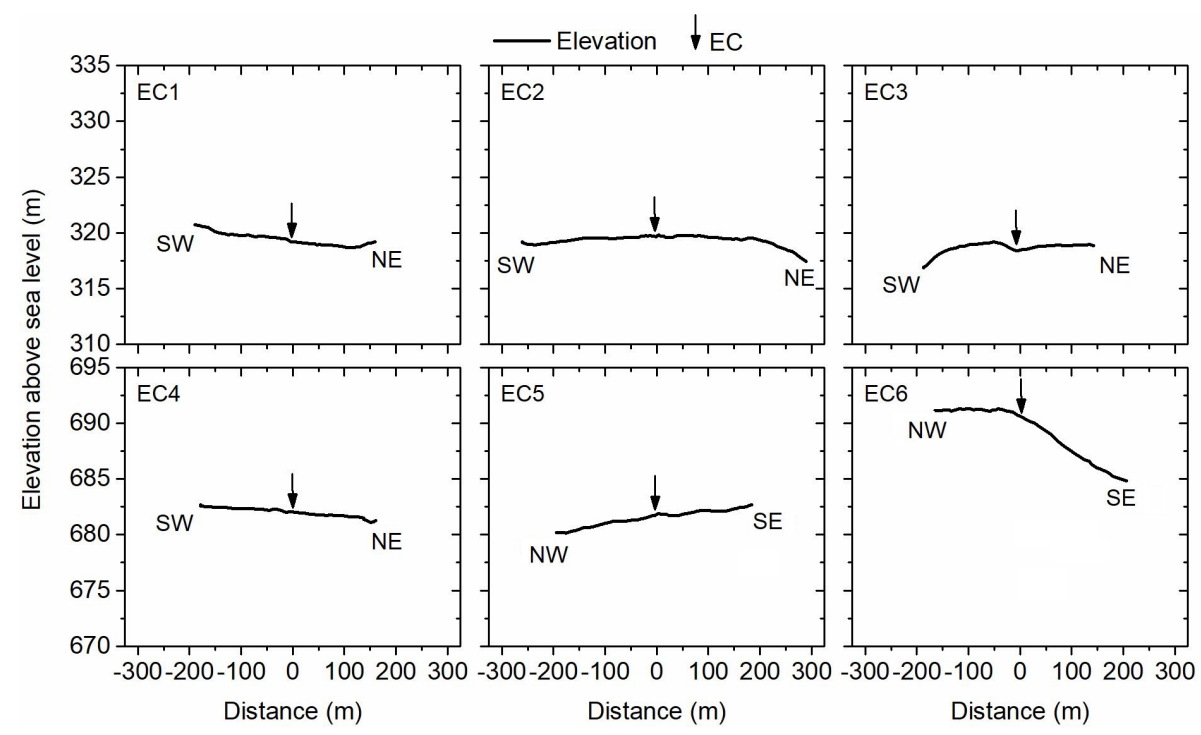

Figure 3. Elevations at EC sites along the dominant wind directions (see Figs. 1 and 3). Arrows present positions of EC stations.

terrain drops with a mean rate of $3.7 \mathrm{~m}$ per $100 \mathrm{~m}$, in SE direction the terrain is nearly flat (slope $=0.3 \%$ ).

\subsection{Energy partitioning at the land surface}

The energy partitioning at the canopy surface of different crop stands is shown, by way of example, for the vegetation period of 2016 (Fig. 4). In that year, five different crops (winter rapeseed $-\mathrm{WR}$, spring barley $-\mathrm{SB}$, winter wheat $-\mathrm{WW}$, silage maize - SM, and grain maize - GM) were grown at the EC sites. From April to June, most of the net radiation was transformed into latent heat at the crop stands, except for SM at EC5. The daytime Bowen ratio was lowest for WW and WR, with 0.14 and 0.13 , respectively. Also GM, SB, and SM at EC6 led to daytime Bowen ratios distinctly below unity (about 0.21 ). Only silage maize at EC5 had a Bowen ratio of about unity, which indicates that the available energy was partitioned into latent and sensible heat in similar proportions. For the WW, SB, and WR sites and years, the ground and sensible heat fluxes were nearly the same and showed a similar diurnal course. At the maize stands, the ground heat flux tended to be higher than the sensible heat flux during the morning hours, while in the afternoon the order switched and more sensible heat than ground heat was formed. At all sites, the measured energy residual was similar to the sensible heat fluxes, ranging from $23 \mathrm{~W} \mathrm{~m}^{-2}$ at EC 3 to $44 \mathrm{~W} \mathrm{~m}^{-2}$ at EC1. The daily net radiation was 149, 133, 134, 130, 138, and $164 \mathrm{~W} \mathrm{~m}^{-2}$ at EC1 to EC6, respectively. The mean daily LE ranged from $54 \mathrm{~W} \mathrm{~m}^{-2}$ at EC5 to $94 \mathrm{~W} \mathrm{~m}^{-2}$ at EC3.
For July to September, the strongest shift in energy partitioning occurred at the WR site. In the afternoon, the Bowen ratio was in the range of unity, and sometimes the half-hourly sensible heat flux was even higher than the latent heat flux. A similar shift was observed at the WW site, but it was weaker than at the WR site. At the GM, SM, and SB sites the largest difference compared with the period April to June was the ratio between the sensible and ground heat flux. From July to September the sensible heat was about twice the ground heat flux. The mean net radiation ranged from $125 \mathrm{~W} \mathrm{~m}^{-2}$ at EC5 to $176 \mathrm{~W} \mathrm{~m}^{-2}$ at EC2, and LE varied from $78 \mathrm{~W} \mathrm{~m}^{-2}$ at $\mathrm{EC} 4$ to $89 \mathrm{~W} \mathrm{~m}^{-2}$ at EC1. The residual energy for this period was $23,28,22,24$ and $16 \mathrm{~W} \mathrm{~m}^{-2}$ at the sites EC1, EC2, EC3, EC4, and EC6, respectively. Note that EC5 data are missing due to damage in the sonic anemometer and gas analyzer.

\subsection{Energy balance closure}

The mean EBR over the 48 years on-site was 0.75 , corresponding to a mean energy residual of $41.6 \mathrm{~W} \mathrm{~m}^{-2}$ (Table 3). The mean annual EBR ranged between 0.62 at EC1 (WW in 2013) and 0.90 at EC4 (SM in 2017). The mean EBR over the six EC stations was highest in $2010(\mathrm{EBR}=0.78)$ and lowest in 2013 (EBR $=0.71)$. Averaged over the period from 2010 to 2017, the best EBC was achieved at EC4 (EBR $=0.82$ ), whereas the largest mean energy gap occurred at the neighboring station EC5. There, the mean residual was $49.0 \mathrm{~W} \mathrm{~m}^{-2}$.

Figure 5 presents the course of monthly mean EBC determined by the OLR for all six stations averaged over the period 2010-2017. In general, the EC method performed best (EBC was highest) over the vegetation period from April to August. The highest EBC was usually found during July and August and distinctly declined over autumn and winter. At 

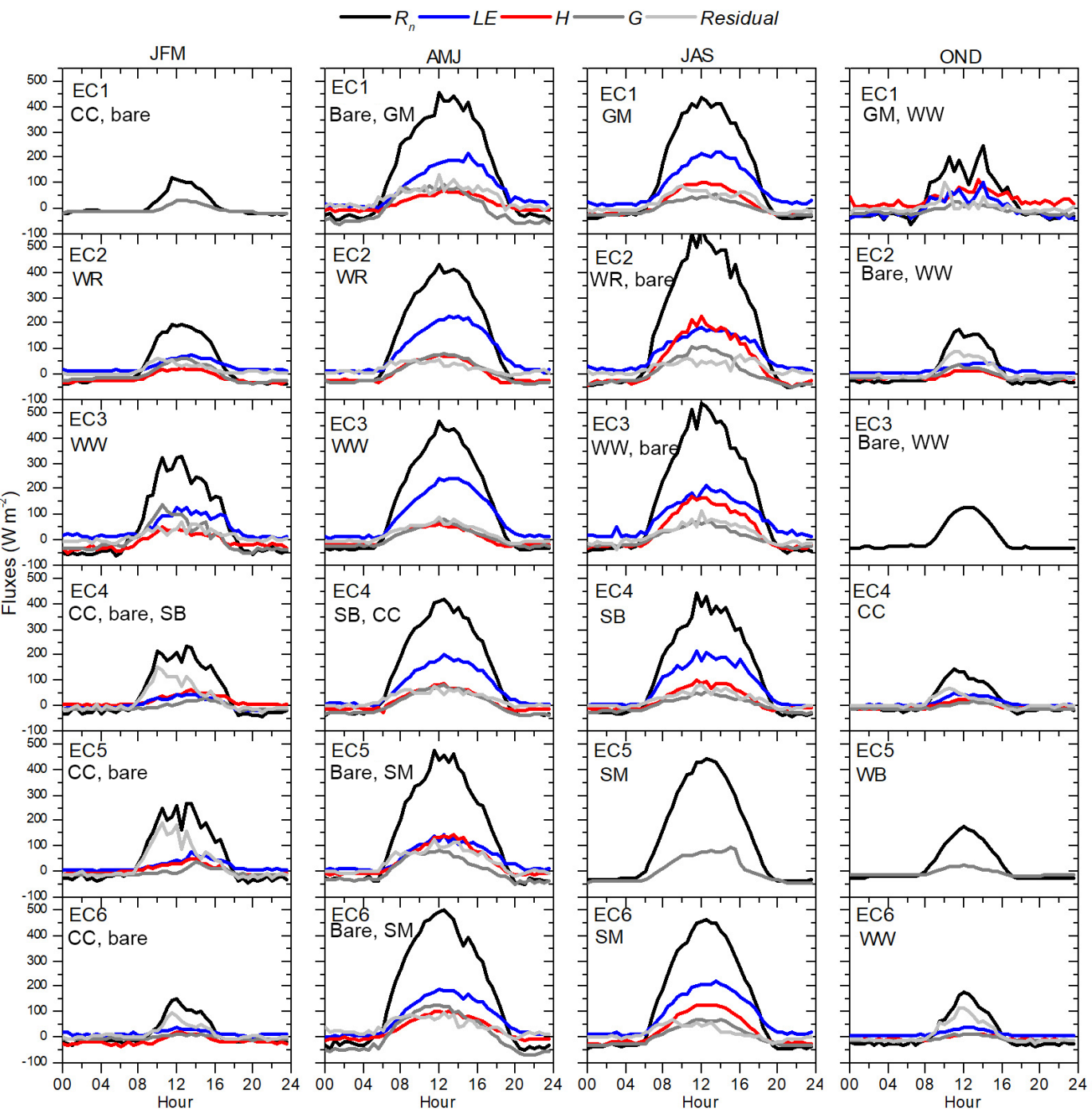

Figure 4. Diurnal courses of energy balance components averaged over 3-month periods in Kraichgau (EC1, EC2, and EC3) and Swabian Jura (EC4, EC5, and EC6) in 2016. Insets denote the different crops grown in 2016; see main text for explanation. Because of energy shortage during winter at the EC1, EC3, EC4, and EC5 sites, the fluxes shown in the JFM and OND graphs were measured only in March and from 1 October to mid-November, respectively.

station EC6, the SJ station equipped with a fuel cell system, for example, the EBC declined to $42 \%$ in January 2016 and $23 \%$ in December 2017. A low EBC was usually associated with a larger variation (see winter months; Fig. 5).

\subsection{What impacts the EBC?}

\subsubsection{Effect of region, station, year, and crop}

The statistical analyses showed that the EBC over the main vegetation period from early April until harvest did not differ between the two regions (Fig. 6a). The EBC was significantly higher at stations EC2 and EC4 $(p<0.001 ; p-$ probability level) than at the other stations (Fig. 6b). The lowest spread in values was observed at station EC4. In 2013 and 2014,
EBC was lower $(p<0.001)$ than in the other 6 years (Fig. 6c). The crops had no significant effect on mean EBC (Fig. 6d). EBC over winter rapeseed showed the highest variation in comparison to the other four crops, varying between $57 \%$ and $88 \%$.

\subsubsection{Effect of wind speed and direction}

Typical for the midlatitudes, the KR sites' prevailing wind direction was from west to east. The fraction of WSW to WNW $\left(240-300^{\circ}\right)$ winds was $43.2 \%, 36.8 \%$ and $33.7 \%$ at EC1, EC2, and EC3, respectively (Fig. 7). The highest wind speeds were also measured within these wind direction sectors. Wind blowing from north- and southward directions was rarely measured $(<10 \%)$. While at EC1 the wind 
Table 3. Annual mean energy balance closure (EBC; slope of linear regression) and energy balance ratio (EBR) at the eddy-covariance stations EC1 to EC6 in Kraichgau and Swabian Jura during 2010-2017. Regressions are based on half-hourly data.

\begin{tabular}{|c|c|c|c|c|c|c|c|c|c|}
\hline \multirow{3}{*}{$\begin{array}{l}\text { Region } \\
\text { Growing season, year }\end{array}$} & \multirow[b]{3}{*}{ Parameter } & \multirow[b]{3}{*}{ Unit } & \multirow{2}{*}{\multicolumn{3}{|c|}{$\begin{array}{c}\text { Kraichgau } \\
\text { Sites }\end{array}$}} & \multirow{2}{*}{\multicolumn{3}{|c|}{$\frac{\text { Swabian Jura }}{\text { Sites }}$}} & \multirow[b]{3}{*}{ Mean } \\
\hline & & & & & & & & & \\
\hline & & & $\mathrm{EC} 1$ & $\mathrm{EC} 2$ & EC3 & EC4 & EC5 & EC6 & \\
\hline \multirow[t]{5}{*}{2010} & Slope & & 0.82 & 0.69 & 0.70 & 0.87 & 0.74 & 0.74 & 0.76 \\
\hline & Intercept & $\mathrm{W} \mathrm{m}^{-2}$ & -2.09 & -5.55 & 8.59 & 3.06 & 2.86 & 11.84 & 3.12 \\
\hline & $R^{2}$ & & 0.91 & 0.85 & 0.84 & 0.94 & 0.86 & 0.90 & 0.88 \\
\hline & EBR & & 0.80 & 0.66 & 0.77 & 0.89 & 0.75 & 0.79 & 0.78 \\
\hline & Residual & $\mathrm{W} \mathrm{m}^{-2}$ & 23.5 & 62.7 & 30.8 & 22.8 & 45.7 & 43.5 & 38.2 \\
\hline \multirow[t]{5}{*}{2011} & Slope & & 0.70 & 0.76 & 0.70 & 0.77 & 0.77 & 0.72 & 0.74 \\
\hline & Intercept & $\mathrm{W} \mathrm{m}^{-2}$ & -4.95 & -0.13 & 5.22 & 1.54 & 12.62 & 4.57 & 3.15 \\
\hline & $R^{2}$ & & 0.95 & 0.94 & 0.86 & 0.92 & 0.88 & 0.94 & 0.92 \\
\hline & EBR & & 0.69 & 0.76 & 0.73 & 0.78 & 0.82 & 0.74 & 0.75 \\
\hline & Residual & $\mathrm{W} \mathrm{m}^{-2}$ & 54.8 & 32.1 & 55.4 & 52.4 & 43.0 & 63.7 & 50.2 \\
\hline \multirow[t]{5}{*}{2012} & Slope & & 0.74 & 0.67 & 0.69 & 0.81 & 0.78 & 0.72 & 0.74 \\
\hline & Intercept & $\mathrm{W} \mathrm{m}^{-2}$ & -3.14 & 7.48 & 4.17 & 3.65 & 6.48 & 2.00 & 3.44 \\
\hline & $R^{2}$ & & 0.96 & 0.86 & 0.94 & 0.90 & 0.89 & 0.93 & 0.91 \\
\hline & EBR & & 0.73 & 0.69 & 0.71 & 0.84 & 0.82 & 0.74 & 0.76 \\
\hline & Residual & $\mathrm{W} \mathrm{m}^{-2}$ & 53.2 & 75.6 & 57.3 & 24.7 & 31.5 & 38.4 & 46.8 \\
\hline \multirow[t]{5}{*}{2013} & Slope & & 0.66 & 0.71 & 0.70 & 0.79 & 0.67 & 0.72 & 0.71 \\
\hline & Intercept & $\mathrm{W} \mathrm{m}^{-2}$ & -6.59 & -0.26 & 4.40 & 4.17 & -0.77 & 3.28 & 0.71 \\
\hline & $R^{2}$ & & 0.95 & 0.96 & 0.95 & 0.92 & 0.94 & 0.93 & 0.94 \\
\hline & EBR & & 0.62 & 0.71 & 0.72 & 0.82 & 0.67 & 0.74 & 0.71 \\
\hline & Residual & $\mathrm{W} \mathrm{m}^{-2}$ & 59.8 & 42.1 & 53.9 & 32.5 & 52.8 & 46.4 & 48.0 \\
\hline \multirow[t]{5}{*}{2014} & Slope & & 0.69 & 0.74 & 0.70 & 0.79 & 0.66 & 0.74 & 0.72 \\
\hline & Intercept & $\mathrm{W} \mathrm{m}^{-2}$ & 4.34 & 5.66 & 4.78 & -2.69 & 0.50 & 0.46 & 2.18 \\
\hline & $R^{2}$ & & 0.89 & 0.86 & 0.92 & 0.93 & 0.93 & 0.94 & 0.91 \\
\hline & EBR & & 0.71 & 0.77 & 0.73 & 0.78 & 0.66 & 0.75 & 0.73 \\
\hline & Residual & $\mathrm{W} \mathrm{m}^{-2}$ & 51.2 & 36.7 & 39.2 & 43.7 & 69.9 & 44.9 & 47.6 \\
\hline \multirow[t]{5}{*}{2015} & Slope & & 0.71 & 0.81 & 0.77 & 0.81 & 0.73 & 0.76 & 0.77 \\
\hline & Intercept & $\mathrm{W} \mathrm{m}^{-2}$ & -5.14 & -5.65 & 8.13 & -2.85 & 7.22 & -4.99 & -0.55 \\
\hline & $R^{2}$ & & 0.96 & 0.94 & 0.92 & 0.94 & 0.87 & 0.94 & 0.93 \\
\hline & EBR & & 0.67 & 0.77 & 0.81 & 0.79 & 0.77 & 0.72 & 0.76 \\
\hline & Residual & $\mathrm{W} \mathrm{m}^{-2}$ & 46.4 & 29.1 & 34.4 & 30.4 & 42.9 & 36.9 & 36.7 \\
\hline \multirow[t]{5}{*}{2016} & Slope & & 0.75 & 0.83 & 0.80 & 0.77 & 0.62 & 0.75 & 0.75 \\
\hline & Intercept & $\mathrm{W} \mathrm{m}^{-2}$ & 7.50 & -5.99 & 3.39 & -0.66 & 5.70 & 3.42 & 2.23 \\
\hline & $R^{2}$ & & 0.89 & 0.92 & 0.94 & 0.92 & 0.84 & 0.88 & 0.90 \\
\hline & EBR & & 0.79 & 0.78 & 0.82 & 0.76 & 0.66 & 0.79 & 0.77 \\
\hline & Residual & $\mathrm{W} \mathrm{m}^{-2}$ & 40.8 & 23.3 & 33.3 & 28.8 & 47.9 & 22.3 & 32.7 \\
\hline \multirow[t]{5}{*}{2017} & Slope & & 0.70 & 0.73 & 0.86 & 0.84 & 0.66 & 0.76 & 0.76 \\
\hline & Intercept & $\mathrm{W} \mathrm{m}^{-2}$ & -6.41 & -0.81 & 2.36 & 10.63 & 11.50 & -0.67 & 2.77 \\
\hline & $R^{2}$ & & 0.96 & 0.95 & 0.93 & 0.86 & 0.87 & 0.94 & 0.92 \\
\hline & EBR & & 0.66 & 0.73 & 0.87 & 0.90 & 0.72 & 0.75 & 0.77 \\
\hline & Residual & $\mathrm{W} \mathrm{m}^{-2}$ & 48.2 & 52.8 & 17.4 & 20.5 & 58.4 & 39.7 & 32.9 \\
\hline \multirow[t]{5}{*}{ Mean } & Slope & & 0.72 & 0.74 & 0.74 & 0.81 & 0.70 & 0.74 & 0.74 \\
\hline & Intercept & $\mathrm{W} \mathrm{m}^{-2}$ & -2.06 & -0.66 & 5.13 & 2.11 & 5.76 & 2.49 & 2.13 \\
\hline & $R^{2}$ & & 0.93 & 0.91 & 0.91 & 0.92 & 0.89 & 0.93 & 0.91 \\
\hline & EBR & & 0.71 & 0.73 & 0.77 & 0.82 & 0.73 & 0.75 & 0.75 \\
\hline & Residual & $\mathrm{W} \mathrm{m}^{-2}$ & 42.7 & 44.3 & 39.9 & 32.0 & 49.0 & 42.0 & 41.6 \\
\hline
\end{tabular}




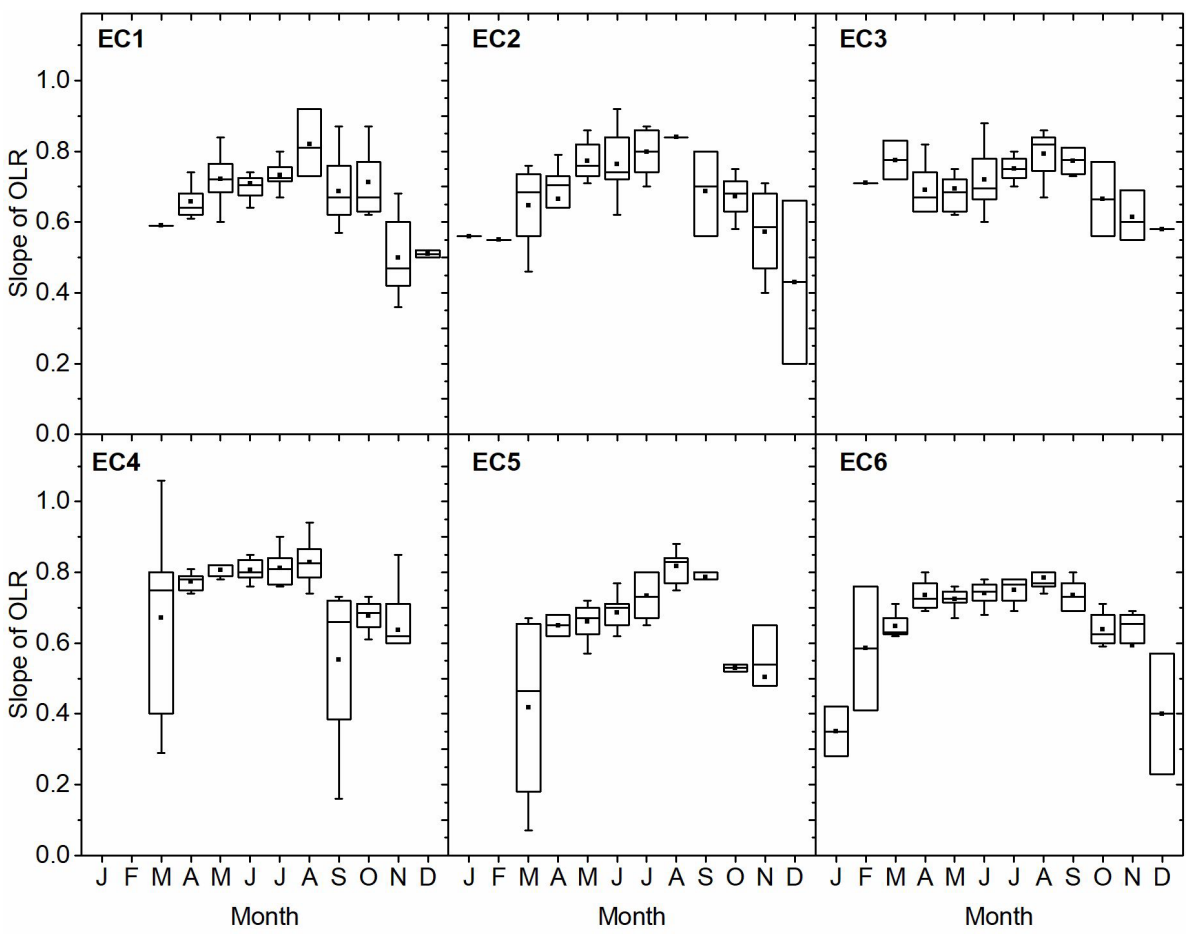

Figure 5. Monthly aggregated energy balance closure (EBC) obtained by ordinary linear regression of turbulent fluxes $(\mathrm{LE}+H)$ against available energy $\left(R_{\mathrm{n}}-G\right)$ for all stations during 2010-2017.
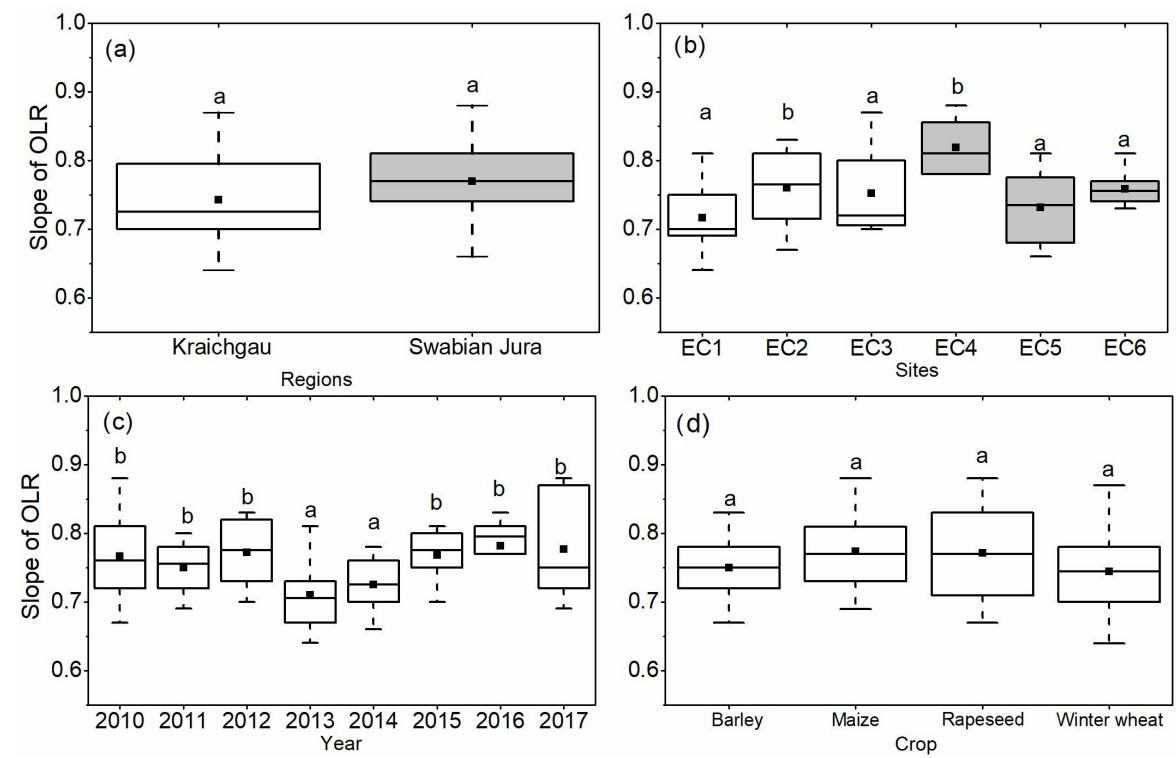

Figure 6. Comparison of energy balance closure (EBC) measured by linear regression, grouped for the different regions, sites, years, and crops. Measurements were conducted from early spring until harvest. Different letters indicate significant ( $\mathrm{a}-$ insignificant, $\mathrm{b}-\mathrm{significant})$ differences between the factor levels at $\alpha=0.05$.

speed averaged $2.9 \mathrm{~m} \mathrm{~s}^{-1}$, at EC2 and EC3 the values were 2.4 and $1.9 \mathrm{~m} \mathrm{~s}^{-1}$, respectively. Moreover, high wind speeds $\left(>6 \mathrm{~m} \mathrm{~s}^{-1}\right.$ ) clearly decreased from the most westerly station (EC1) to the most easterly station (EC3). At EC1, EC2, and
EC3, the share of these high wind speeds was $4.6 \%, 3.3 \%$, and $0.2 \%$, respectively.

In SJ, the wind blew mostly from westerly or easterly directions (Fig. 7). The wind from the $240-300^{\circ}$ sector was less than in KR, with shares of $14.4 \%, 25.5 \%$, and $26.6 \%$ 

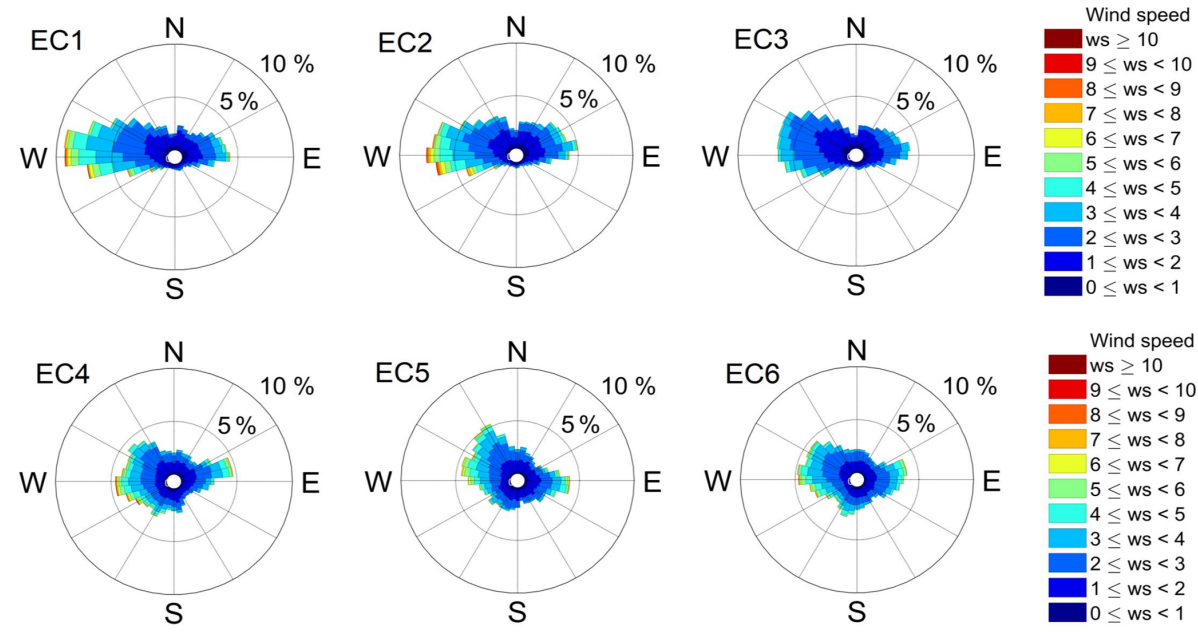

Figure 7. Distribution of wind direction and wind speed $\left(\mathrm{m} \mathrm{s}^{-1}\right)$ from 2010 to 2017 in Kraichgau (EC1-EC3) and Swabian Jura (EC4-EC6).

at EC4, EC5, and EC6, respectively. At EC5, more wind was recorded from the NW sector $\left(300-330^{\circ}\right)$. Mean horizontal wind speeds at EC4, EC5, and EC6 were 2.44, 2.38, and $2.51 \mathrm{~m} \mathrm{~s}^{-1}$, respectively. Wind speeds above $6 \mathrm{~m} \mathrm{~s}^{-1}$ made up 2.0 (EC4), 1.7 (EC5), and 1.3\% (EC6) of all measured wind speeds in SJ.

The distribution of the EBR as a function of wind direction is shown in Fig. 8. The EBR was averaged for $30^{\circ}$ wind sectors over all available daytime data (global radiation $>10 \mathrm{~W} \mathrm{~m}^{-2}$ ). At the KR sites, the highest EBR was achieved when the wind blew from westerly directions, which is the prevailing wind direction. Wind from northern and southern directions was related to a lower EBR. Particularly wind from the south was associated with an EBR below 0.6 at all three stations. This phenomenon was most pronounced at station EC1. Also at the SJ sites, the highest EBR usually coincided with wind from the prevailing direction. One exception is the high EBR at EC4 for the south-southeast sector. At EC4, for six out of the 12 wind sectors, EBR was above 0.8 . In contrast, at EC5 and EC6, the EBR exceeded 0.8 in only three wind sectors. At all stations, the EBR was lowest $(<0.6)$ for winds from the northeast (Fig. 9).

\subsubsection{Effect of atmospheric conditions}

This section evaluates the EBR as a function of buoyancy, shear, and atmospheric stability. For this purpose, we plotted the EBR against the kinematic virtual temperature flux $\left(w^{\prime} T_{\mathrm{v}}^{\prime}\right.$, proxy for buoyancy), friction velocity $\left(u^{*}\right.$, proxy for shear), and the stability parameter $\zeta$ (Fig. 10). Again, only half-hourly daytime fluxes $\left(R_{\mathrm{S}}>10 \mathrm{~W} \mathrm{~m}^{-2}\right)$ were evaluated. The plot EBR versus $w^{\prime} T_{\mathrm{v}}^{\prime}$ shows a vast scatter at weak buoyancy. Here, the EBR ranges from plus four to minus four. The scatter decreases substantially as the modulus of $w^{\prime} T_{\mathrm{v}}^{\prime}$ increases. Note that $w^{\prime} T_{\mathrm{v}}^{\prime}<-0.15 \mathrm{~K} \mathrm{~m} \mathrm{~s}^{-1}$ were measured only at stations EC2 and EC4.
Plotting the EBR against friction velocity also reveals a large scatter, which narrows as friction velocity (shear) increases. The scatter, however, does not narrow as much as for increasing buoyancy. During neutral or stable atmospheric conditions, the EBR showed a large spread (Fig. 10). In contrast, this range distinctly declined when the stability parameter reached strongly negative values, indicative of highly unstable conditions. An EBR above unity or below zero was rarely observed under these conditions.

From the total dataset, only $7 \%$ of daytime measurements were made under stable conditions, $34 \%$ under unstable conditions, and $59 \%$ under neutral conditions (Table 4). During unstable conditions, the EBC and EBR at all sites were slightly lower compared to neutral conditions. During neutral conditions, however, the standard deviation (SD) of EBR was about twice as high as under unstable conditions. During stable conditions, the EBC and EBR were systematically lower than at unstable and neutral conditions. At EC4, for example, the EBR was 0.78 and 0.85 under neutral and unstable conditions, respectively. Under stable conditions, the value declined to 0.41. Moreover, the huge spread in the EBR under stable conditions is underlined by its high $\mathrm{SD}$, which is about 3 times the mean value.

\subsubsection{Effect of footprint}

Figure 11 shows exemplary footprints for sites EC3 and EC5 in 2015, illustrating the substantially different size of flux source areas determined for the different months. Both fields were cropped with maize. At EC3, EBC continuously increased from $68 \%$ in June to $79 \%$ in July and $90 \%$ in August. In this period, as the maize plants got taller, the footprint area became continuously smaller. A similar relation between footprint area and EBC was observed at EC5: the larger the footprint, the lower the $\mathrm{EBC}$. A linear regression between EBC and the $90 \%$ footprint area of all data from 
(a)

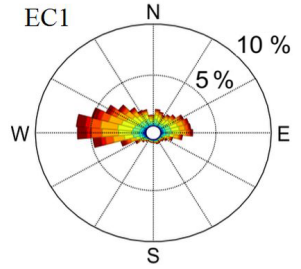

(b)

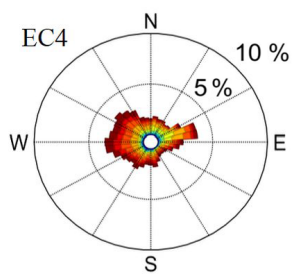

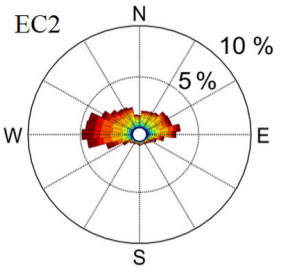

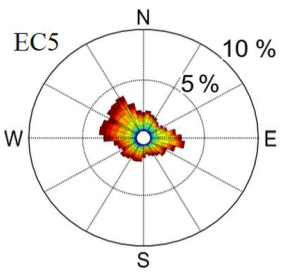

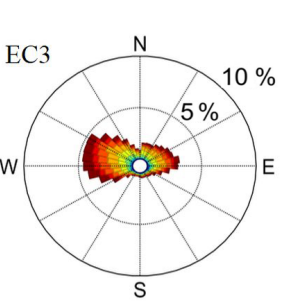

EBR $\geq$

$0.9<\mathrm{EBR}<1$

$0.8 \leq \mathrm{EBR}<0.9$

$0.7 \leq \mathrm{EBR}<0.8$

$0.6 \leq \mathrm{EBR}<0.7$

$0.5 \leq \mathrm{EBR}<0.6$

$0.4 \leq \mathrm{EBR}<0.5$

$0.3<\mathrm{EBR}<0.4$

$0.2 \leq \mathrm{EBR}<0.3$

$0.1 \leq \mathrm{EBR}<0.2$ $\leq \mathrm{EBR}<0$

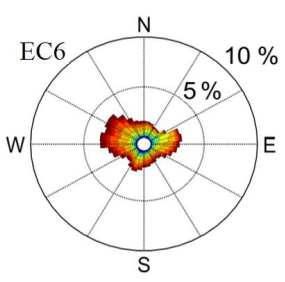

$\mathrm{EBR} \geq 1$

$0.9 \leq \mathrm{EBR}<1$

$0.8 \leq \mathrm{EBR}<0.9$

$0.7 \leq \mathrm{EBR}<0.8$

$0.6 \leq \mathrm{EBR}<0.7$

$0.5 \leq \mathrm{EBR}<0.6$

$0.4 \leq \mathrm{EBR}<0.5$

$0.3 \leq \mathrm{EBR}<0.4$

$0.2 \leq \mathrm{EBR}<0.3$

$0.1 \leq \mathrm{EBR}<0.2$

$0 \leq \mathrm{EBR}<0.1$

Figure 8. Distribution of half-hourly energy balance ratios (EBR) in terms of wind direction at eddy-covariance (EC) stations during the 2010-2017 study period. Spike lengths in diagram show relative frequency of wind directions; color of legend shows EBR. This is shown for (a) Kraichgau and (b) Swabian Jura.

(a)

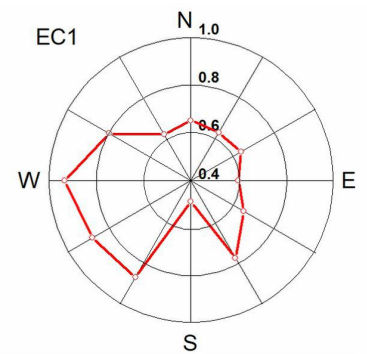

(b)

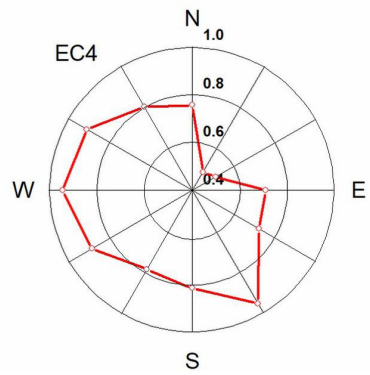

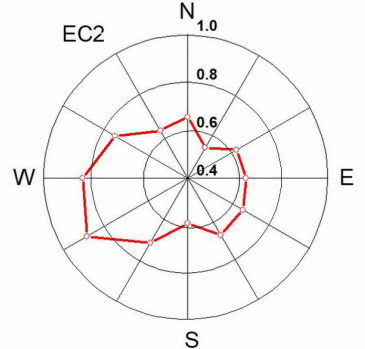

$\mathrm{N}$

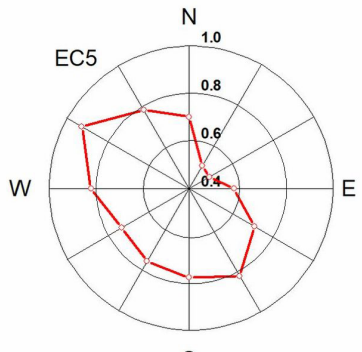

$\mathrm{s}$
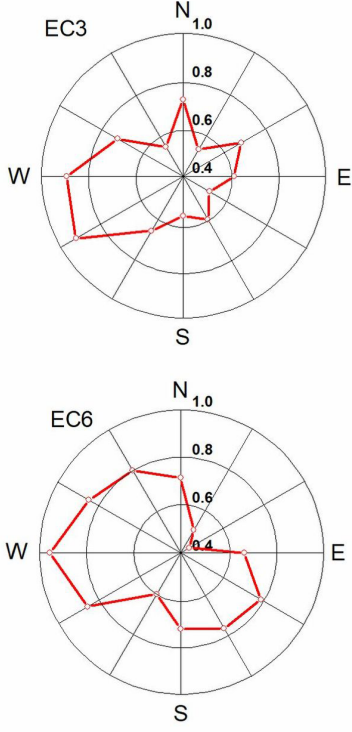

Figure 9. Half-hourly energy balance ratio (EBR) averaged for $30^{\circ}$ wind sectors at the six eddy-covariance (EC) stations during the 2010 to 2017 study period. This is shown for (a) Kraichgau and (b) Swabian Jura.

2015 confirmed this relation (not shown). Although $R^{2}$ was only 0.21 , the slope of $-1.25 \% \mathrm{ha}^{-1}\left(0.50 \% \mathrm{ha}^{-1}\right.$; standard error) per hectare was significantly different from zero. The intercept of the regression was $79 \%$.

\section{Discussion}

\subsection{EBC and energy balance components}

From July to September, daily mean $R_{\mathrm{n}}$ varied between 125 and $176 \mathrm{~W} \mathrm{~m}^{-2}$. Similar ranges of $R_{\mathrm{n}}$ were observed over maize in Livraga, Italy (Masseroni et al., 2014). The latent and sensible heat fluxes varied strongly over the observational period. In early covering crops (winter rapeseed, winter wheat, and winter barley), LE was about 2 to 3 times higher than $H$ in the period AMJ (April-May-June), while in the period JAS (July-August-September), LE and $H$ were in a similar range (Fig. 4; EC3-WW, EC4-SB). The period JAS is when the ripening and harvest of cereals and winter rapeseed occurs as well as post-harvest management such as tillage and seeding of cover crops or winter rapeseed. During AMJ, the patterns of LE and $H$ at EC5 and EC6 differed, even though the maize was sown on similar days of the year (7 May at EC5 and 3 May at EC6). This can be explained by 

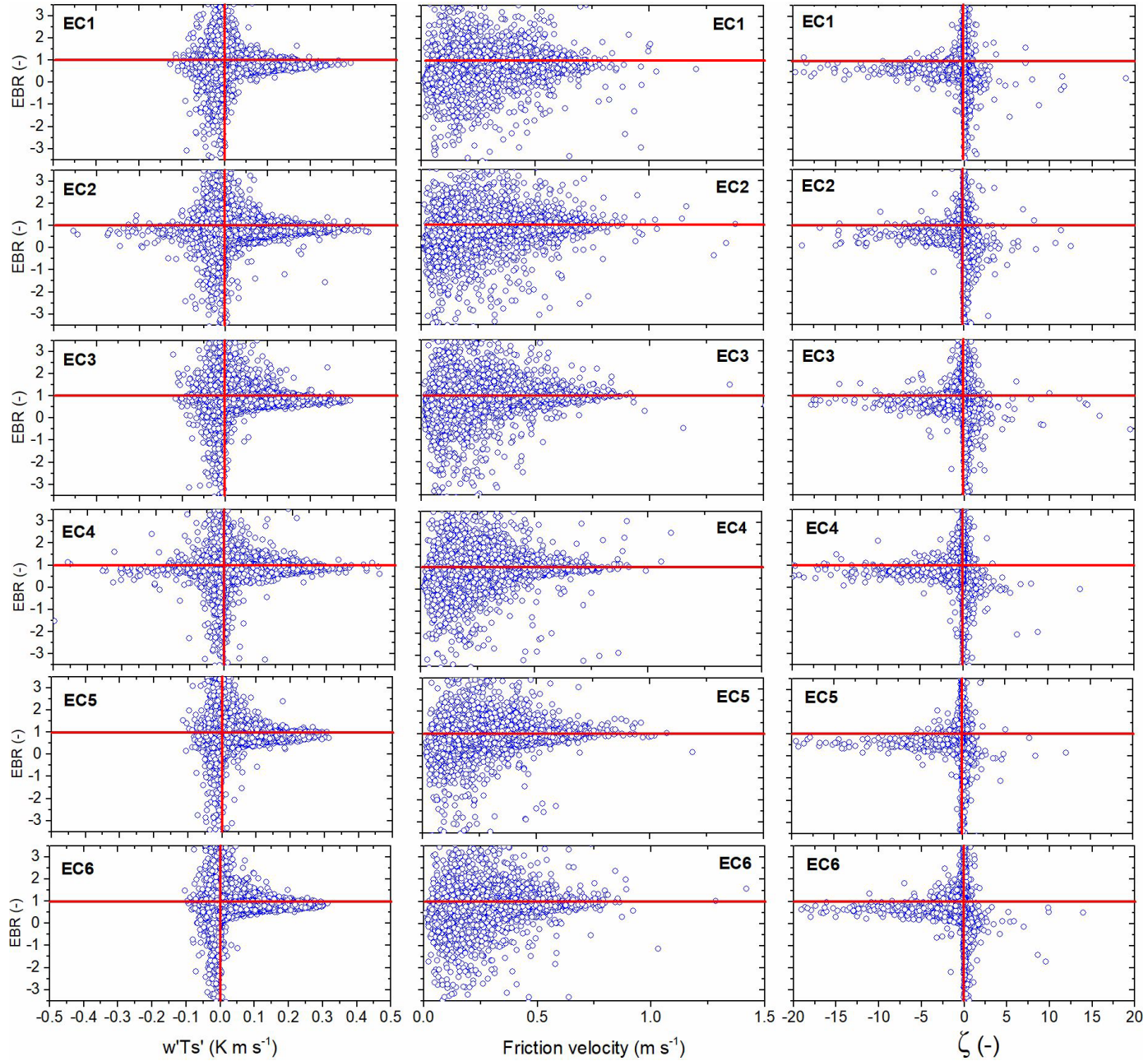

Figure 10. The mean energy balance ratio (EBR) as a function of buoyancy flux $\left(w^{\prime} T_{\mathrm{s}}^{\prime}\right)$, friction velocity $\left(u^{*}\right)$, and the stability parameter $(\zeta)$ during the 2010-2017 study period.

the substantially higher leaf area index at EC6 $(0.74 \pm 0.15)$ compared to EC5 $(0.35 \pm 0.06)$, measured on 22 June.

The mean EBR of the 48 years on-site was 0.75 (Table 3). In comparison, Wilson et al. (2002) reported an EBR of 0.84, on average, for the 50 analyzed FLUXNET years on-site, ranging from 0.34 to 1.69 . In three agricultural and one industrial site in South Korea, the mean value varied between 0.46 and 0.83 (Kim et al., 2014). Majozi et al. (2017) found a mean EBR of 0.93 at a semi-arid savannah site in South Africa, over a period of 15 years.

The slopes of the OLR and EBR differed by a maximum of $5 \%$, which is consistent with previously published data. Such a small difference points to a high reliability of the presented EC measurements (Wilson et al., 2002). The highest annual EBC occurred at EC4 (87\% in 2010), the second highest at EC2 (83\% in 2016), and the lowest at EC5 (62\% in 2016). The lowest EBC was observed mainly in the cold, non-growing season, which may be attributed to insufficient thermally and mechanically induced turbulence (Franssen et al., 2010) as well as to freezing (Varmaghani et al., 2016).

The incomplete EBC in our dataset has several potential explanations. One is related to the neglected minor storage terms (Eshonkulov et al., 2019; Masseroni et al., 2014; Meyers and Hollinger, 2004). Importantly, considering minor storage terms is not straightforward, because they are not measured when conventional EC equipment is used. Only the energy fixed and released by photosynthesis and respiration can be directly derived from EC data, because the net $\mathrm{CO}_{2}$ flux is generally measured. Considering minor storage terms in calculating the EBC at a maize field improved the mean value from $87 \%$ to $91 \%$ (Xu et al., 2017) and from $81 \%$ to $86 \%$ (Masseroni et al., 2014). Eshonkulov et al. (2019) demonstrated that the contribution of minor storage and flux terms over winter wheat in southwestern Germany was largest during the main vegetation period in May. During this month the minor terms helped to close the energy balance by an additional $7 \%-8 \%$. 
Table 4. Energy balance closure (EBC) as indicated by the slope of linear regression of turbulent vs. available energy and energy balance ratio (EBR) under different atmospheric stability conditions. EBC and EBR are given as site-specific averages from 2010 to 2017 . SD is standard deviation.

\begin{tabular}{|c|c|c|c|c|c|c|c|c|}
\hline \multirow{3}{*}{$\begin{array}{l}\text { Region } \\
\text { Stability condition }\end{array}$} & \multirow[b]{3}{*}{ Parameter } & \multirow[b]{3}{*}{ Unit } & \multicolumn{3}{|c|}{ Kraichgau } & \multicolumn{3}{|c|}{ Swabian Jura } \\
\hline & & & \multicolumn{3}{|c|}{ Sites } & \multicolumn{3}{|c|}{ Sites } \\
\hline & & & EC1 & $\mathrm{EC} 2$ & EC3 & EC4 & EC5 & EC6 \\
\hline \multirow[t]{8}{*}{ Unstable } & Slope & & 0.69 & 0.74 & 0.70 & 0.79 & 0.68 & 0.74 \\
\hline & Intercept & $\mathrm{W} \mathrm{m}^{-2}$ & -6.14 & -9.12 & 9.58 & 0.21 & 1.18 & -2.57 \\
\hline & $R^{2}$ & & 0.87 & 0.85 & 0.83 & 0.87 & 0.84 & 0.8 \\
\hline & EBR & & 0.67 & 0.69 & 0.73 & 0.78 & 0.68 & 0.73 \\
\hline & $\mathrm{SD}(\mathrm{EBR})$ & & 0.32 & 0.34 & 0.37 & 0.28 & 0.32 & 0.27 \\
\hline & Residual & $\mathrm{W} \mathrm{m}^{-2}$ & 94.7 & 82.0 & 81.4 & 59.1 & 95.1 & 78.4 \\
\hline & SD (Residual) & $\mathrm{W} \mathrm{m}^{-2}$ & 62.3 & 61.5 & 67.3 & 54.4 & 68.2 & 58.3 \\
\hline & $N^{*}$ & & 5478 & 4992 & 5926 & 7145 & 5755 & 8533 \\
\hline \multirow[t]{8}{*}{ Neutral } & Slope & & 0.73 & 0.79 & 0.75 & 0.82 & 0.75 & 0.77 \\
\hline & Intercept & $\mathrm{W} \mathrm{m}^{-2}$ & -0.95 & 0.04 & 10.22 & 3.58 & 7.44 & 1.59 \\
\hline & $R^{2}$ & & 0.90 & 0.88 & 0.87 & 0.89 & 0.85 & 0.89 \\
\hline & EBR & & 0.72 & 0.78 & 0.73 & 0.85 & 0.78 & 0.78 \\
\hline & SD (EBR) & & 0.63 & 0.67 & 0.64 & 0.83 & 0.70 & 0.65 \\
\hline & Residual & $\mathrm{W} \mathrm{m}^{-2}$ & 61.5 & 43.3 & 48.2 & 34.37 & 52.1 & 45.6 \\
\hline & SD (Residual) & $\mathrm{W} \mathrm{m}^{-2}$ & 59.1 & 60.0 & 62.2 & 50.6 & 64.4 & 52.8 \\
\hline & $N^{*}$ & & 9957 & 10781 & 11180 & 11575 & 9563 & 12149 \\
\hline \multirow[t]{8}{*}{ Stable } & Slope & & 0.66 & 0.69 & 0.71 & 0.57 & 0.57 & 0.48 \\
\hline & Intercept & $\mathrm{W} \mathrm{m}^{-2}$ & -3.25 & -1.88 & 6.48 & 4.06 & 6.17 & 3.01 \\
\hline & $R^{2}$ & & 0.86 & 0.82 & 0.86 & 0.61 & 0.68 & 0.52 \\
\hline & EBR & & 0.41 & 0.46 & 0.56 & 0.41 & 0.30 & 0.33 \\
\hline & $\mathrm{SD}(\mathrm{EBR})$ & & 1.34 & 0.67 & 1.56 & 1.48 & 1.44 & 1.51 \\
\hline & Residual & $\mathrm{W} \mathrm{m}^{-2}$ & 18.7 & 13.3 & 6.4 & 7.3 & 6.23 & 6.6 \\
\hline & SD (Residual) & $\mathrm{W} \mathrm{m}^{-2}$ & 31.5 & 29.0 & 34.5 & 29.2 & 36.2 & 28.9 \\
\hline & $N^{*}$ & & 1292 & 1398 & 1642 & 1105 & 787 & 1075 \\
\hline
\end{tabular}

* Number of data points.

\subsection{The effect of meteorological conditions and surface-layer turbulent parameters}

In both KR and SJ, the EBR was highest for winds blowing from the prevailing wind direction. These winds were associated with high wind speeds favoring well-developed turbulent conditions. This is consistent with other studies. Xin et al. (2018), for example, also found that winds with high speeds blowing from the prevailing direction yielded consistently higher EBC compared to other directions. Kim et al. (2014), for example, grouped EBR into two different categories, one with a lower EBR $(<0.75)$ and one with a higher EBR ( $>0.75$ ), and observed for their four research sites that the EBR was higher at high wind speed.

Figure 10 shows that the spread of the EBR distinctly narrowed at high friction velocities $\left(u^{*} \geq 0.5\right)$. Prior studies have noted the importance of $u^{*}$ on the EBC. Anderson and Wang (2014) found that, under these conditions, EBC was closed on days with continuous turbulence. Results of the hourly daytime EBR and $u^{*}$ showed a strong relationship at our sites (Fig. 10). This is consistent with other studies carried out in selected croplands such as irrigated sugarcane (Anderson and Wang, 2014), maize plantations (Masseroni et al., 2014), and rice fields (Kim et al., 2014). Sánchez et al. (2010) also reported that EBR was $>0.90$ when high friction velocities prevailed $\left(>0.8 \mathrm{~m} \mathrm{~s}^{-1}\right)$ at a boreal forest site in Finland. Mauder et al. (2013) investigated EBC at the TERENO site in Lackenberg (Germany) and found that it was almost closed. They explain this result by the very good turbulent mixing and the high homogeneity at this site. This confirms that, at high $u^{*}$, the production of high-frequency fluxes is elevated (Fratini and Mauder, 2014).

At our study sites, neutral conditions dominated $(\sim 60 \%)$, followed by unstable conditions $(\sim 34 \%)$ and stable conditions (6\%; Table 4). Importantly, average EBR changed from $0.67( \pm 0.32)$ to $0.72( \pm 0.69)$ and $0.41( \pm 1.33)$ during unstable, neutral, and stable conditions, respectively (SD in brackets). Under stable conditions, the EBR was lowest and had the largest variation. Averaged over all EC stations, the slope 

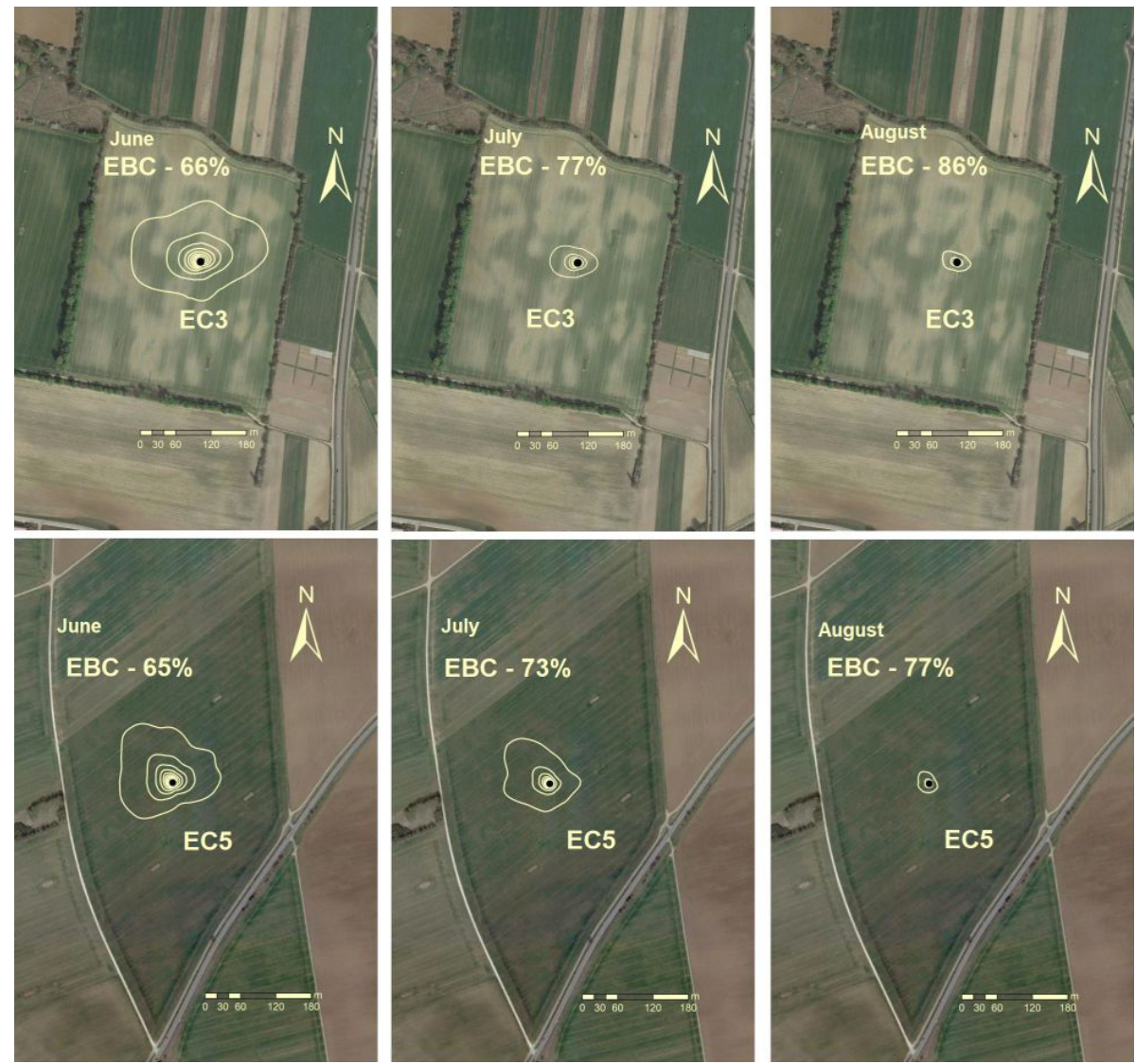

Figure 11. Footprint area of EC3 and EC5 in selected months of 2015 and the corresponding energy balance closure (EBC). Black points represent positions of EC stations. Yellow lines indicate relative areal contributions to total flux in $10 \%$ steps, where the outmost yellow line indicates the area from which $90 \%$ of measured fluxes originated. The satellite image was taken from Google Earth (images from 31 March 2017 and 30 March 2014 for EC3 and EC5, respectively).

of OLR under neutral conditions was slightly higher than under unstable conditions. This is also evident in the mean and variance of the calculated energy residuals. The average residuals under stable, neutral, and unstable conditions were $9.7( \pm 31.5), 47.5( \pm 58.2)$, and $81.5( \pm 62.0) \mathrm{W} \mathrm{m}^{-2}$, respectively. The coefficient of variation was highest under stable conditions and decreased over neutral to unstable conditions. This result differs from previous studies. Mauder et al. (2010) reported a residual energy close to zero for a cropland in Ontario, Canada, under stable conditions, peaking at $150 \mathrm{~W} \mathrm{~m}^{-2}$ under neutral conditions and decreasing to $100 \mathrm{~W} \mathrm{~m}^{-2}$ under unstable conditions.

The scatter of EBR versus buoyancy flux at EC2 and EC4, the two stations with the highest EBC, differed from those of the other stations (Fig. 10). At these two sites, strong negative buoyancy fluxes below $-0.15 \mathrm{~K} \mathrm{~m} \mathrm{~s}^{-1}$ were recorded. This means that the atmosphere was not heated by the land surface but that the land surface was significantly heated by the atmosphere. Such a situation points to a stable boundary layer (SBL). Lan et al. (2018) report that they measured the highest buoyancy fluxes under a weak SBL with strong surface shear. They argue that the strong mechanical shear produced at the ground favors the development of turbulent eddies with larger scales that enhance vertical mixing of momentum and heat transporting the warm air aloft downward and the surface cold air upward. Moreover, the mechanical mixing weakens the magnitude of the mean temperature gradient and allows turbulent eddies with larger vertical scales to develop. Conversely, under a SBL, weak winds occur near the surface, and turbulent eddies are depressed and detached from the boundary leading to suppressed vertical mixing.

Several studies recommended considering secondary circulations to achieve a better EBC (Foken et al., 2010; Kidston et al., 2010; Mauder et al., 2010). Those studies postulate that heterogeneity-induced and buoyancy-driven quasistationary circulations are probably the dominant processes behind underestimated energy fluxes. The studies that suggested the use of an averaging period higher than 30 min usually refer to unstable conditions. These studies suggested that averaging periods of $2-4 \mathrm{~h}$ are often needed to statistically resolve the largest convective turbulent eddies or also nonstationary mesoscale motions that sometimes can modulate 
turbulent fluxes (Mahrt, 1998). Larger averaging improved short-term EBC during the diurnal hours in the Salentum peninsula of Apulia, Italy (Cava et al., 2008). In considering secondary circulations, different time averaging intervals can be used instead of the standard 30 min period. Although a 60 min interval might be suitable for capturing the major turbulent fluxes (Kilinc et al., 2012), in most cases the standard $30 \mathrm{~min}$ period is still sufficient (Kidston et al., 2010). The classical averaging period of $30 \mathrm{~min}$ can be a proper choice for unstable or neutral conditions. A shorter averaging period is suitable for capturing energy fluxes in very stable conditions (Sun et al., 2012; Vickers and Mahrt, 2006). Finding an optimum averaging period is a very complex and nearly impossible task. This is because atmospheric turbulence changes irregularly, and there is no clear-cut "switch" in time. Therefore, the averaging time could be modified during raw data processing. In practice, however, this is unlikely, because it drastically increases the complexity of data processing (Lenschow et al., 1994). Moreover, the sources of secondary circulations are unclear, and they are most probably not well linked with the locally measured available energy. Accordingly, excluding secondary circulations in EC measurements can be locally meaningful. Recently, a new method, known as ogive optimization, was proposed by Sievers et al. (2015). The method enables the separation of lowfrequency influences from vertical turbulent fluxes for isolating the local exchange processes of interest.

Although EC measurements contain uncaptured energy components, the flux data are used, among others, to evaluate models and interpret simulation results. In such studies, EC flux data are usually post-closed, i.e., the measured turbulent fluxes are adjusted so as to close the energy balance (Ingwersen et al., 2015). The standard approach is the Bowen-ratio post-closure method (Twine et al., 2000). It assumes that the missing energy has the same Bowen ratio as the measured turbulent fluxes. This approach, however, may introduce a systematic bias to simulated surface energy fluxes (Chen and $\mathrm{Li}, 2012$ ). Analyses of the energy imbalance by Ingwersen et al. (2011) showed that soil water contents simulated by a land surface model agreed better with measurements when the residual was fully assigned to $H$. As discussed by Charuchittipan et al. (2014), secondary near-surface circulations attributed to low frequencies mainly transport sensible heat. Therefore, they proposed a new alternative energy balance correction method they termed the Buoyancy flux ratio. At very large Bowen ratios $(>10)$, the Bowen-ratio post-closure and buoyancy flux correction methods yield similar results. At Bowen ratios ranging from 0.1 to 0.2 , which are typical for croplands during the main growing period, the Buoyancy flux ratio method assigns most of the energy residual $(>50 \%)$ to the sensible heat flux. The Bowen-ratio method, in contrast, distributes most of it ( $>90 \%)$ to latent heat. As long as the composition of the residual remains unknown, it is important to communicate the possible error in EC flux data, for example with the post-closure method uncertainty band (PUB; Ingwersen et al., 2015). Working with only one post-closure method may result in serious misinterpretations in model-data comparisons (Ingwersen et al., 2018).

\subsection{The effect of the instrumental setup}

At the SJ sites, we found a particularly low EBR in the wind sector $0-90^{\circ}$. The CSAT3 sensor was oriented mostly to $225^{\circ}$ so that the sector $30-90^{\circ}$ was located behind the anemometer head. To substantiate the idea that the anemometer negatively influences EC measurement quality, and taking the data from EC4 as an example, we recalculated EBR across all years, excluding the wind directions of the sector $0-90^{\circ}$. This increased the mean EBC in 2010-2017 by 4 percentage points, from $80 \%$ to $84 \%$ (data not shown). Friebel et al. (2009) used a wind tunnel experiment to show that there is a $40^{\circ}$ shadow zone behind the sonic anemometer where the measured wind speeds were reduced by up to $16 \%$. Within a shadow zone of about $20^{\circ}$ behind the anemometer, the turbulent spectra were corrupted. Our findings indicate that under field conditions the shadow zone was even somewhat wider (about $60^{\circ}$ ). A practical solution for measuring reliable fluxes when winds blow from the back of the anemometer could be to operate an anemometer tandem: a first anemometer orientated in the prevailing wind direction and a second one in the opposite direction. Whether this setup could solve the problem requires further investigation.

\subsection{Relationships between EBC and footprint}

Accurate measurements of energy balance components are important to achieve a good EBC. In this context, one key requirement is that the EC station be located in a place that represents the fluxes from the area of interest (Burba and Anderson, 2010). According to those authors, the terrain must be horizontal and uniform. Three parameters are needed in footprint analysis: measurement height, surface roughness, and atmospheric stability. When turbulent fluxes originate from a horizontal and homogeneous surface, the footprint depends solely on the distance between the location of the measurement point and the emission element. We found a distinct tendency that the smaller the footprint, the higher the EBC. We give two explanations. First, the smaller the footprint, the higher the chance that the assumption of a homogeneous source area is fulfilled. Second, the smaller the footprint, the better the scale match between the measurement of available energy and turbulent fluxes. Alfieri and Blanken (2012) found that variations of surface energy fluxes over tens of meters ranged from 30 to $40 \mathrm{~W} \mathrm{~m}^{-2}$ using single-point (immobile) and mobile EC towers at a uniform site (Colorado, USA). They concluded that a single-point EC tower cannot capture all the relevant energy fluxes, because they vary spatially. Our results confirm that if the footprint is small, the EBC from EC measurements is better, which can be interpreted as a reduction in the variation of surface energy fluxes. 
Many studies claimed that surface heterogeneity is a potential reason for the energy imbalance (Stoy et al., 2013; $\mathrm{Xu}$ et al., 2017). The latter authors reported that EBC decreased with increasing surface heterogeneity. The degree of heterogeneity was derived from high-resolution remote sensing images and land surface temperatures. To handle this effect, some authors recommend using direction-specific coefficients that indicate the degree of heterogeneity. For example, Panin et al. (1998) introduced a heterogeneity factor that comprises surface parameters such as roughness, radiation, and the thermal humidity of the internal boundary layer. That factor can be used for data interpretation. Nonetheless, deploying heterogeneity factors still does not explain how the residual energy is composed. The lack of EBC at the KR sites might partly reflect katabatic advection (Heinesch et al., 2008; Kutsch et al., 2008), which results from stable atmospheric conditions and occurs especially in hillslope areas (Loescher et al., 2006; Mauder et al., 2010). Moreover, complex topography can induce advective fluxes (Feigenwinter et al., 2008; Rebmann et al., 2010). The former landfill site located about $500 \mathrm{~m}$ south of the fields in KR (Fig. 1) might have been responsible for advective fluxes, since its elevation is approximately $41 \mathrm{~m}$ higher than the study sites. Moreover, the topography could also affect EBC. The elevation transects show that the immediate terrain surrounding the stations EC3, EC5, and EC6 is not totally flat (Fig. 4). This is a well-known problem for micrometeorological field measurements (Wilczak et al., 2001). At EC1, EC2, and EC4, however, the terrain can be considered flat.

\section{Conclusions}

We evaluated the EBC of long-term EC measurements at six different cropland sites in two contrasting environmental regions in southwestern Germany. EBC depended on how well thermally and mechanically induced turbulence was developed. On average, $25 \%$ of the available energy was not detected by our EC stations, with the lowest annual imbalances (energy residual) of $17 \%$ in KR and $13 \%$ in SJ. This range of EBC is common in cropland, and such recovery rates must be accepted in heterogeneous landscapes. We interpret the range of the highest mean annual EBC (83\% at KR, $87 \%$ at $\mathrm{SJ}$ ) as the upper detection limit of the EC method at our sites and settings. During winter months and under stable atmospheric conditions, EBC was problematic. EBC was negatively affected by (i) stable atmospheric conditions, (ii) nonhorizontal or heterogeneous source area, (iii) larger obstacles in the landscape, i.e., the former landfill site that may have induced adjective flux components, and (iv) flow distortions of winds that first traveled past the back head of the anemometer, which reduces wind speed and corrupts the spectral characteristics of turbulence at specific wind directions. EBC was positively affected as the footprint area decreased, probably because this tends to decrease the heterogeneity of the source area and improves the match of available energy measured locally with the mean available energy in the footprint.

Data availability. The dataset can only be made available upon request.

Author contributions. TS and JI designed the research. AP and HDW processed EC data (PK in 2017), and PH measured LAI measurements at EC5 and EC6. RE, JI, and AP contributed towards interpretation and analysis of the results, and RE, JI, AP, AP, and TKDW wrote the paper and contributed towards improvement of the original draft and finalization of the paper.

Competing interests. The authors declare that they have no conflict of interest.

Acknowledgements. This study was financially supported by the German Research Foundation (DFG) in the frame of the Research Unit (RU) 1695 "Structure and function of agricultural landscapes under global climate change - Processes and projections on a regional scale". Part of the work was sponsored by an Erasmus Mundus grant "TIMUR - Training of Individuals through Mobility from Uzbek Republic to EU (referenced as GA NO 213-2723/001001-EM Action 2)". Additionally, this work received support from the funding by the Collaborative Research Centre 1253 CAMPOS (Project 7: Stochastic Modelling Framework), funded by the German Research Foundation (DFG, Grant Agreement SFB 1253/1 2017).

We thank Paul Stoy for handling the paper and one anonymous reviewer and Marcelo Zeri for helpful and constructive comments.

We would like to thank the following farmers: Hans Bosch Sr., Günter Bosch Jr., in KR (EC1, EC2, and EC3), and HansGerhard Fink (EC4), Gerhard and Markus Hermann (EC5), and Reichart GbR (EC6) in SJ for the permission to conduct measurements in their fields. The authors would also like to thank the technical staff Benedikt Prechter, Felix Baur, Christian Schade, and Thomas Schreiber.

Edited by: Paul Stoy

Reviewed by: Marcelo Zeri and one anonymous referee

\section{References}

Alfieri, J. G. and Blanken, P. D.: How representative is a point? The spatial variability of surface energy fluxes across short distances in a sand-sagebrush ecosystem, J. Arid. Environ., 87, 4249, https://doi.org/10.1016/j.jaridenv.2012.04.010, 2012.

Anderson, R. G. and Wang, D.: Energy budget closure observed in paired eddy covariance towers with increased and continuous daily turbulence, Agr. Forest Meteorol., 184, 204-209, https://doi.org/10.1016/j.agrformet.2013.09.012, 2014.

Baldocchi, D. D., Falge, E., Gu, L., Olson, R., Hollinger, D., Running, S., Anthoni, P., Bernhofer, C., Davis, K., Evans, R., 
Fuentes, J., Goldstein, A., Katul, G., Law, B., Lee, X., Malhi, Y., Meyers, T., Munger, W., Oechel, W., Paw, K. T. U., Pilegaard, K., Schmid, H. P., Valentini, R., Verma, S., Vesala, T., Wilson, K., and Wofsy, S.: FLUXNET: A new tool to study the temporal and spatial variability of ecosystem-scale carbon dioxide, water vapor, and energy flux densities, B. Am. Meteorol. Soc., 82, 2415-2434, https://doi.org/10.1175/15200477(2001)082<2415:FANTTS>2.3.CO;2, 2001.

Bretz, F., Hothorn, T., and Westfall, P.: Multiple Comparisons Using R, Chapman and Hall, CRC Press, London, 2011.

Burba, G.: Eddy covariance method for scientific, industrial, agricultural and regulatory applications, LI-COR Biosciences, 2013.

Burba, G. and Anderson, D.: A brief practical guide to eddy covariance flux measurements: Principles and workflow examples for scientific and industrial applications, LI-COR Biosciences, Lincoln, Nebraska, USA, available at: http://www.ncbi.nlm.nih.gov/ pubmed/18767616 (last access: 17 July 2018), 2010.

Cava, D., Contini, D., Donateo, A., and Martano, P.: Analysis of short-term closure of the surface energy balance above short vegetation, Agr. Forest Meteorol., 148, 82-93, https://doi.org/10.1016/j.agrformet.2007.09.003, 2008.

Charuchittipan, D., Babel, W., Mauder, M., Leps, J. P., and Foken, T.: Extension of the averaging time in eddy-covariance measurements and its effect on the energy balance closure, Bound.Lay. Meteorol., 152, 303-327, https://doi.org/10.1007/s10546014-9922-6, 2014.

Chen, Y.-Y. and Li, M.-H.: Determining adequate averaging periods and reference coordinates for eddy covariance measurements of surface heat and water vapor fluxes over mountainous terrain, Terr. Atmos. Ocean. Sci., 23, 685, https://doi.org/10.3319/TAO.2012.05.02.01(Hy), 2012.

Demyan, M. S., Ingwersen, J., Funkuin, Y. N., Ali, R. S., Mirzaeitalarposhti, R., Rasche, F., Poll, C., Müller, T., Streck, T., Kandeler, E., and Cadisch, G.: Partitioning of ecosystem respiration in winter wheat and silage maize-modeling seasonal temperature effects, Agr. Ecosyst. Environ., 224, 131-144, https://doi.org/10.1016/j.agee.2016.03.039, 2016.

Du, Q., Liu, H. Z., Feng, J. W., and Wang, L.: Effects of different gap filling methods and land surface energy balance closure on annual net ecosystem exchange in a semiarid area of China, Sci. China Earth Sci., 57, 1340-1351, https://doi.org/10.1007/s11430-013-4756-5, 2014.

Eshonkulov, R., Poyda, A., Ingwersen, J., Pulatov, A., and Streck, T.: Improving the energy balance closure over a winter wheat field by accounting for minor storage terms, Agr. Forest Meteorol., 264, 283-296, https://doi.org/10.1016/J.AGRFORMET.2018.10.012, 2019.

Eugster, W. and Merbold, L.: Eddy covariance for quantifying trace gas fluxes from soils, SOIL, 1, 187-205, https://doi.org/10.5194/soil-1-187-2015, 2015.

Faraway, J. J.: Linear models with R, CHAPMAN \& HALL/CRC, Boca Raton London NewYork Washington, DC, 2014.

Feigenwinter, C., Bernhofer, C., Eichelmann, U., Heinesch, B., Hertel, M., Janous, D., Kolle, O., Lagergren, F., Lindroth, A., Minerbi, S., Moderow, U., Montagnani, L., Queck, R., Rebmann, C., Vestin, P., Yernaux, M., Zeri, M., Ziegler, W., and Aubinet, M.: Comparison of horizontal and vertical advective $\mathrm{CO}_{2}$ fluxes at three forest sites, Agr. Forest Meteorol., 148, 12-24, https://doi.org/10.1016/j.agrformet.2007.08.013, 2008.
Foken, T.: Micrometeorology, 1st ed., Springer-Verlag Berlin Heidelberg, 2008.

Foken, T.: The energy balance closure problem: an overview, Ecol. Appl., 18, 1351-1367, https://doi.org/10.1890/06-0922.1, 2008 b.

Foken, T., Göockede, M., Mauder, M., Mahrt, L., Amiro, B., and Munger, W.: Post-Field Data Quality Control, in Handbook of Micrometeorology, 181-208, Kluwer Academic Publishers, Dordrecht, 2004.

Foken, T., Mauder, M., Liebethal, C., Wimmer, F., Beyrich, F., Leps, J. P., Raasch, S., DeBruin, H. A. R., Meijninger, W. M. L., and Bange, J.: Energy balance closure for the LITFASS-2003 experiment, Theor. Appl. Climatol., 101, 149160, https://doi.org/10.1007/s00704-009-0216-8, 2010.

Franssen, H. J. H., Stöckli, R., Lehner, I., Rotenberg, E., and Seneviratne, S. I.: Energy balance closure of eddy-covariance data: A multisite analysis for European FLUXNET stations, Agr. Forest Meteorol., 150, 1553-1567, https://doi.org/10.1016/j.agrformet.2010.08.005, 2010.

Fratini, G. and Mauder, M.: Towards a consistent eddy-covariance processing: an intercomparison of EddyPro and TK3, Atmos. Meas. Tech., 7, 2273-2281, https://doi.org/10.5194/amt-7-22732014, 2014.

Friebel, H. C., Herrington, T. O., and Benilov, A. Y.: Evaluation of the flow distortion around the Campbell Scientific CSAT3 sonic anemometer relative to incident wind direction, J. Atmos. Ocean. Tech., 26, 582-592, https://doi.org/10.1175/2008JTECHO550.1, 2009.

Göckede, M., Markkanen, T., Hasager, C. B., and Foken, T.: Update of a footprint-based approach for the characterisation of complex measurement sites, Bound.-Lay. Meteorol., 118, 635-655, https://doi.org/10.1007/s10546-005-6435-3, 2006.

Gregory, R. W., Ben, B., Lodewijk, B., Robert, G., Wolfgang, H., Andy, L., Thomas, L., Martin, M., Arni, M., Steffen, M., Marc, S., and Bill, V.: gplots: Various R programming tools for plotting data, available at: https://cran.r-project.org/web/packages/gplots/ index.html (last access: 17 July 2018), 2009.

Gregory, R. W., Bolker, B., Gorjanc, G., Grothendieck, G., Korosec, A., Lumley, T., MacQueen, D., Magnusson, A., and Rogers, J.: Package "gdata". Various R programming tools for data manipulation, available at: https://cran.r-project.org/web/packages/ gdata/index.html (last access: 17 July 2018), 2017.

Heinesch, B., Yernaux, Y., and Aubinet, M.: Dependence of $\mathrm{CO}_{2}$ advection patterns on wind direction on a gentle forested slope, Biogeosciences, 5, 657-668, https://doi.org/10.5194/bg-5-6572008, 2008.

Hothorn, T., Bretz, F., and Westfall, P.: Simultaneous Inference in General Parametric Models, Biometrical J., 50, 346-363, 2017.

Imukova, K., Ingwersen, J., Hevart, M., and Streck, T.: Energy balance closure on a winter wheat stand: comparing the eddy covariance technique with the soil water balance method, Biogeosciences, 13, 63-75, https://doi.org/10.5194/bg-13-63-2016, 2016.

Ingwersen, J., Steffens, K., Högy, P., Warrach-Sagi, K., Zhunusbayeva, D., Poltoradnev, M., Gäbler, R., Wizemann, H. D., Fangmeier, A., Wulfmeyer, V., and Streck, T.: Comparison of Noah simulations with eddy covariance and soil water measurements at a winter wheat stand, Agr. Forest Meteorol., 151, 345-355, https://doi.org/10.1016/j.agrformet.2010.11.010, 2011. 
Ingwersen, J., Imukova, K., Högy, P., and Streck, T.: On the use of the post-closure methods uncertainty band to evaluate the performance of land surface models against eddy covariance flux data, Biogeosciences, 12, 2311-2326, https://doi.org/10.5194/bg-122311-2015, 2015.

Ingwersen, J., Högy, P., Wizemann, H. D., Warrach-Sagi, K., and Streck, T.: Coupling the land surface model Noah-MP with the generic crop growth model Gecros: Model description, calibration and validation, Agr. Forest Meteorol., 262, 322-339, https://doi.org/10.1016/J.AGRFORMET.2018.06.023, 2018.

IUSS Working Group WRB: World reference base for soil resources 2014, International soil classification system for naming soils and creating legends for soil maps, FAO, Rome, Italy, 2014.

Jacobs, A. F. G., Heusinkveld, B. G., and Holtslag, A. A. M.: Towards closing the surface energy budget of a midlatitude grassland, Bound.-Lay. Meteorol., 126, 125-136, https://doi.org/10.1007/s10546-007-9209-2, 2008.

Kaimal, J. C. and Gaynor, J. E.: Another look at sonic thermometry, Bound.-Lay. Meteorol., 56, 401-410, 1991.

Kidston, J., Brümmer, C., Black, T. A., Morgenstern, K., Nesic, Z., McCaughey, J. H., and Barr, A. G.: Energy balance closure using eddy covariance above two different land surfaces and Implications for $\mathrm{CO}_{2}$ flux measurements, Bound.-Lay. Meteorol., 136, 193-218, https://doi.org/10.1007/s10546-010-9507-y, 2010.

Kilinc, M., Beringer, J., Hutley, L. B., Haverd, V., and Tapper, N.: An analysis of the surface energy budget above the world's tallest angiosperm forest, Agr. Forest Meteorol., 166-167, 2331, https://doi.org/10.1016/J.AGRFORMET.2012.05.014, 2012.

Kim, S., Lee, Y.-H., Kim, K. R., and Park, Y.-S.: Analysis of surface energy balance closure over heterogeneous surfaces, AsiaPacific, J. Atmos. Sci., 50, 1-13, https://doi.org/10.1007/s13143014-0045-2, 2014.

Kljun, N., Rotach, M. W., and Schmid, H. P.: A three-dimensional backward lagrangian footprint, Bound.-Lay. Meteorol., 103, 205-226, 2002.

Kljun, N., Calanca, P., Rotach, M. W., and Schmid, H. P.: A simple parameterisation for flux footprint predictions, Bound.-Lay. Meteorol., 112, 503-523, https://doi.org/10.1023/B:BOUN.0000030653.71031.96, 2004.

Kljun, N., Calanca, P., Rotach, M. W., and Schmid, H. P.: A simple two-dimensional parameterisation for Flux Footprint Prediction (FFP), Geosci. Model Dev., 8, 3695-3713, https://doi.org/10.5194/gmd-8-3695-2015, 2015.

Kohsiek, W., Liebethal, C., Foken, T., Vogt, R., Oncley, S. P., Bernhofer, C., and Debruin, H. A. R.: The Energy Balance Experiment EBEX-2000. Part III: Behaviour and quality of the radiation measurements, Bound.-Lay. Meteorol., 123, 55-75, https://doi.org/10.1007/s10546-006-9135-8, 2007.

Kutsch, W. L., Kolle, O., Rebmann, C., Knohl, A., Ziegler, W., and Schulze, E. D.: Advection and resulting $\mathrm{CO}_{2}$ exchange uncertainty in a tall forest in central Germany, Ecol. Appl., 18, 13911405, https://doi.org/10.1890/06-1301.1, 2008.

Lan, C., Liu, H., Li, D., Katul, G. G., and Finn, D.: Distinct turbulence structures in stably stratified boundary layers with weak and strong surface shear, J. Geophys. Res.-Atmos., 123, 78397854, https://doi.org/10.1029/2018JD028628, 2018.

Lenschow, D. H., Mann, J., Kristensen, L., Lenschow, D. H., Mann, J., and Kristensen, L.: How long is long enough when measuring fluxes and other turbulence statistics?, J. At- mos. Ocean. Tech., 11, 661-673, https://doi.org/10.1175/15200426(1994)011<0661:HLILEW>2.0.CO;2, 1994.

LI-COR Inc.: EddyPro Software. Instruction manual, LI-COR Biosciences, 2012.

Loescher, H. W., Law, B. E., Mahrt, L., Hollinger, D. Y., Campbell, J., and Wofsy, S. C.: Uncertainties in, and interpretation of, carbon flux estimates using the eddy covariance technique, J. Geophys. Res, 111, 21-90, https://doi.org/10.1029/2005JD006932, 2006.

Mahrt, L.: Flux sampling errors for aircraft and towers, J. Atmos. Ocean. Tech., 15, 416-429, https://doi.org/10.1175/15200426(1998)015<0416:FSEFAA>2.0.CO;2, 1998.

Majozi, N. P., Mannaerts, C. M., Ramoelo, A., Mathieu, R., Nickless, A., and Verhoef, W.: Analysing surface energy balance closure and partitioning over a semi-arid savanna FLUXNET site in Skukuza, Kruger National Park, South Africa, Hydrol. Earth Syst. Sci., 21, 3401-3415, https://doi.org/10.5194/hess-21-34012017, 2017.

Masseroni, D., Corbari, C., and Mancini, M.: Limitations and improvements of the energy balance closure with reference to experimental data measured over a maize field, Atmosfera, 27, 335-352, https://doi.org/10.1016/S0187-6236(14)70033-5, 2014.

Mauder, M. and Foken, T.: Documentation and instruction manual of the eddy-covariance software package TK3, Arbeitsergebnisse, Nr. 46, Universität Bayreuth, Abt. Mikrometeorologie, Bayreuth, 2011.

Mauder, M., Desjardins, R. L., Pattey, E., and Worth, D.: An attempt to close the daytime surface energy balance using spatiallyaveraged flux measurements, Bound.-Lay. Meteorol., 136, 175191, https://doi.org/10.1007/s10546-010-9497-9, 2010.

Mauder, M., Cuntz, M., Drüe, C., Graf, A., Rebmann, C., Schmid, H. P., Schmidt, M., and Steinbrecher, R.: A strategy for quality and uncertainty assessment of long-term eddycovariance measurements, Agr. Forest Meteorol., 169, 122-135, https://doi.org/10.1016/j.agrformet.2012.09.006, 2013.

Meyers, T. P. and Hollinger, S. E.: An assessment of storage terms in the surface energy balance of maize and soybean, Agr. Forest Meteorol., 125, 105-115, https://doi.org/10.1016/j.agrformet.2004.03.001, 2004.

Moore, C. J.: Frequency response corrections for eddy correlation systems, Bound.-Lay. Meteorol., 37, 17-35, https://doi.org/10.1007/BF00122754, 1986.

Oncley, S. P., Foken, T., Vogt, R., Kohsiek, W., DeBruin, H. A. R., Bernhofer, C., Christen, A., van Gorsel, E., Grantz, D., Feigenwinter, C., Lehner, I., Liebethal, C., Liu, H., Mauder, M., Pitacco, A., Ribeiro, L., and Weidinger, T.: The energy balance experiment EBEX-2000. Part I: overview and energy balance, Bound.Lay. Meteorol., 123, 1-28, https://doi.org/10.1007/s10546-0079161-1, 2007.

Panin, G. N., Tetzlaff, G., and Raabe, A.: Inhomogeneity of the land surface and problems in the parameterization of surface fluxes in natural conditions, Theor. Appl. Climatol., 60, 163-178, https://doi.org/10.1007/s007040050041, 1998.

Peng, D., Zhang, X., Wu, C., Huang, W., Gonsamo, A., Huete, A. R., Didan, K., Tan, B., Liu, X., and Zhang, B.: Intercomparison and evaluation of spring phenology products using National Phenology Network and AmeriFlux observations in the 
contiguous United States, Agr. Forest Meteorol., 242, 33-46, https://doi.org/10.1016/J.AGRFORMET.2017.04.009, 2017.

Piepho, H. P., Buchse, A., and Richter, C.: A mixed modelling approach for randomized experiments with repeated measures, J. Agron. Crop Sci., 190, 230-247, https://doi.org/10.1111/j.1439037X.2004.00097.x, 2004.

Ping, Y., Qiang, Z., Shengjie, N., Hua, C., and Xiyu, W.: Effects of the soil heat flux estimates on surface energy balance closure over a semi-arid grassland, Acta Meteorol. Sin., 25, 774-782, https://doi.org/10.1007/s13351-011-0608-4, 2011.

Pinheiro, J., Bates, D., DebRoy, S., Sarkar, D., and Team, R. C.: nlme: Linear and nonlinear mixed effects models, $\mathrm{R}$ package version 3.1-125, 2016.

Pirk, N., Sievers, J., Mertes, J., Parmentier, F.-J. W., Mastepanov, M., and Christensen, T. R.: Spatial variability of $\mathrm{CO}_{2}$ uptake in polygonal tundra: assessing low-frequency disturbances in eddy covariance flux estimates, Biogeosciences, 14, 3157-3169, https://doi.org/10.5194/bg-14-3157-2017, 2017.

$\mathrm{R}$ Core Team: A language and environment for statistical computing. R foundation for statistical computing, Vienna, Austria, 2014.

Rebmann, C., Zeri, M., Lasslop, G., Mund, M., Kolle, O., Schulze, E., and Feigenwinter, C.: Treatment and assessment of the $\mathrm{CO}_{2}$ exchange at a complex forest site in Thuringia, Germany, Agr. Forest Meteorol., 150, 684-691, https://doi.org/10.1016/j.agrformet.2009.11.001, 2010.

Sánchez, J. M., Caselles, V., and Rubio, E. M.: Analysis of the energy balance closure over a FLUXNET boreal forest in Finland, Hydrol. Earth Syst. Sci., 14, 1487-1497, https://doi.org/10.5194/hess-14-1487-2010, 2010.

Schmid, H. P.: Footprint modeling for vegetation atmosphere exchange studies: A review and perspective, Agr. Forest Meteorol., 113, 159-183, https://doi.org/10.1016/S0168-1923(02)00107-7, 2002.

Schotanus, P., Nieuwstadt, F. T. M., and De Bruin, H. A. R.: Temperature measurement with a sonic anemometer and its application to heat and moisture fluxes, Bound.-Lay. Meteorol., 26, 81-93, https://doi.org/10.1007/BF00164332, 1983.

Sievers, J., Papakyriakou, T., Larsen, S. E., Jammet, M. M., Rysgaard, S., Sejr, M. K., and Sørensen, L. L.: Estimating surface fluxes using eddy covariance and numerical ogive optimization, Atmos. Chem. Phys., 15, 2081-2103, https://doi.org/10.5194/acp-15-2081-2015, 2015.

Stoy, P. C., Mauder, M., Foken, T., Marcolla, B., Boegh, E., Ibrom, A., Arain, M. A., Arneth, A., Aurela, M., Bernhofer, C., Cescatti, A., Dellwik, E., Duce, P., Gianelle, D., van Gorsel, E., Kiely, G., Knohl, A., Margolis, H., Mccaughey, H., Merbold, L., Montagnani, L., Papale, D., Reichstein, M., Saunders, M., Serrano-Ortiz, P., Sottocornola, M., Spano, D., Vaccari, F., and Varlagin, A.: A data-driven analysis of energy balance closure across FLUXNET research sites: The role of landscape scale heterogeneity, Agr. Forest Meteorol., 171-172, 137-152, https://doi.org/10.1016/j.agrformet.2012.11.004, 2013.

Stull, B. R.: An introduction to boundary layer meteorology, Kluwer Acd.Publ., Dordrecht, Boston, London, 1988.
Sun, J., Mahrt, L., Banta, R. M., Pichugina, Y. L., Sun, J., Mahrt, L., Banta, R. M., and Pichugina, Y. L.: Turbulence regimes and turbulence intermittency in the stable boundary layer during CASES-99, J. Atmos. Sci., 69, 338-351, https://doi.org/10.1175/JAS-D-11-082.1, 2012.

Sun, X. M., Zhu, Z. L., Wen, X. F., Yuan, G. F., and Yu, G. R.: The impact of averaging period on eddy fluxes observed at ChinaFLUX sites, Agr. Forest Meteorol., 137, 188-193, https://doi.org/10.1016/j.agrformet.2006.02.012, 2006.

Twine, T. E., Kustas, W. P., Norman, J. M., Cook, D. R., Houser, P. R., Meyers, T. P., Prueger, J. H., Starks, P. J., and Wesel, M. L.: Correcting eddy-covariance flux understimates over a grassland, Agr. Forest Meteorol., 103, 229-317, 2000.

Varmaghani, A., Eichinger, W. E., and Prueger, J. H.: A diagnostic approach towards the causes of energy balance closure problem, Open J. Mod. Hydrol., 6, 101-114, 2016.

Vickers, D. and Mahrt, L.: Quality control and flux sampling problems for tower and aircraft data, J. Atmos. Ocean. Tech., 14, 512-526, https://doi.org/10.1175/15200426(1997)014<0512:QCAFSP>2.0.CO;2, 1997.

Vickers, D. and Mahrt, L.: A solution for flux contamination by mesoscale motions with very weak turbulence, Bound.-Lay. Meteorol., 118, 431-447, https://doi.org/10.1007/s10546-005-9003y, 2006.

Webb, E. K., Pearman, G. I., and Leuning, R.: Correction of flux measurements for density effects due to heat and water vapour transfer, Q. J. Roy. Meteorol. Soc., 106, 85-100, https://doi.org/10.1002/qj.49710644707, 1980.

Wilczak, J. M., Oncley, S. P., and Stage, S. A.: Sonic anemometer tilt correction algorithms, Bound.-Lay. Meteorol., 99, 127-150, https://doi.org/10.1023/A:1018966204465, 2001.

Wilson, K., Goldstein, A., Falge, E., Aubinet, M., Baldocchi, D., Berbigier, P., Bernhofer, C., Ceulemans, R., Dolman, H., Field, C., Grelle, A., Ibrom, A., Law, B., Kowalski, A., Meyers, T., Moncrieff, J., Monson, R., Oechel, W., Tenhunen, J., Valentini, R., and Verma, S.: Energy balance closure at FLUXNET sites, Agr. Forest Meteorol., 113, 223-243, https://doi.org/10.1016/S0168-1923(02)00109-0, 2002.

Wizemann, H. D., Ingwersen, J., Högy, P., Warrach-Sagi, K., Streck, T., and Wulfmeyer, V.: Three year observations of water vapor and energy fluxes over agricultural crops in two regional climates of Southwest Germany, Meteorol. Z., 24, 39-59, https://doi.org/10.1127/metz/2014/0618, 2014.

Xin, Y.-F., Chen, F., Zhao, P., Barlage, M., Blanken, P., Chen, Y.-L., Chen, B., and Wang, Y.-J.: Surface energy balance closure at ten sites over the Tibetan plateau, Agr. Forest Meteorol., 259, 317 328, https://doi.org/10.1016/j.agrformet.2018.05.007, 2018.

Xu, Z., Liu, S., Shi, W., and Wang, J.: Assessment of the energy balance closure under advective conditions and Its impact using remote sensing data, Am. Meteorol. Soc., 56, 127-140, https://doi.org/10.1175/JAMC-D-16-0096.1, 2017.

Zeri, M. and Sá, L. D. A.: The impact of data gaps and quality control filtering on the balances of energy and carbon for a Southwest Amazon forest, Agr. Forest Meteorol., 150, 1543-1552, https://doi.org/10.1016/j.agrformet.2010.08.004, 2010. 